\title{
AFRIKAI CITERÁK
}

\author{
BRAUER-BENKE JÓZSEF
}

A romantika időszakában Kelet-Európa népeinek a népdal, majd idővel a hangszeres népzene is ősi autentikus forrást jelentett, amit napjaink neofolklorizmusa is kincsként öriz és próbál megörizni, továbbadni - illetve, amiből mindenkor merítve lehet a modern feldolgozásokat is „hitelesíteni”. Ezzel párhuzamosan a modern nyugati társadalmak - hagyományos népi kultúrájuk már nem lévén - felfedezték az általuk leigázott és korábban lenézett szubszaharai Afrika népcsoportjai hagyományos kultúrájának a modern élethez leginkább adaptálható szeletét, a zenét és annak hangszereit. Afrikával kapcsolatban elmaradhatatlan bevezető gondolat, miszerint az afrikaiak számára a zene a születéstöl kezdve az élet elhagyhatatlan része, mert szinte valamennyi hétköznapi tevékenységet, legyen az vallásos szertartás, ünnep, munka vagy gyász, de még a harcot is autentikus zene kíséri. Szintén hozzájárult az „Afrika és a zene” gondolattársításhoz, hogy az afrikai zene szerteágazó hatásai különféle zenei múfajokban, ún. world music, black music, afroamerikai és afrolatin zene, stb. fúziókban is megnyilvánulnak. Emiatt - habár mára már egyre nyilvánvalóbb, hogy Afrikában sem zenélt mindenki, mert ott is adott népcsoport vagy társadalmi csoport specialistái foglalkoztak a zenei jellegü szolgáltatásokkal és a többiek csak hallgatták vagy táncoltak -, a még mindig dominánsan afrocentrikus világzene hatásának következményeként általánosan elterjedt nézet, miszerint az afrikaiaknak „,vérükben van a zene”. Mindebből kifolyólag Afrikára mint afféle a külső hatásoktól mentes, ősi és autentikus zenét és hangszereket megőrző kontinensre szokás tekinteni, sőt annak ellenére, hogy Délkelet-Ázsia hagyományos társadalmainak népcsoportjai mindennapjait legalább annyira áthatja a zene, mint az afrikai népcsoportokét, hasonló képzettársítás esetükben nem áll fenn, így általánosságban nem beszélünk ,ázsiai zenéröl”. A gyarmatosítás elötti időszak külső hatásoktól mentes Afrika-képét nagyban árnyalja, hogy a történeti néprajz vizsgálatai alapján - főleg a hangszerek eredetének tekintetében - Délkelet-Ázsia már évszázadok óta folyamatos hatással lehetett Afrikára. Elöször a 19. század végén Frobenius vetette fel annak lehetőségét, hogy indonéz kulturális befolyások érték Kelet-Afrikát és jutottak el Nyugat-Afrikába, ahol még mindig kimutathatóak (Frobenius, 1897, 7). Hasonló következtetésre jutott Jones, aki rámutatott, hogy Kelet, Közép- és Nyugat-Afrika bizonyos területein az időszámításunk első századaiban indonéz eredetü népesség jelenhetett meg és általuk terjedhettek el a különböző xilofontípusok, a 
pentaton és a heptaton hangrendszerek (Jones, 1964, 126). Az Afrikát érő indonéz kulturális hatások elméletével szembehelyezkedve Jeffrey viszont annak lehetőségét vetette fel, miszerint nem Indonézia hatott Afrikára, hanem az arab kereskedőknek köszönhetően afrikai zenei hatások érték az indonéz térséget (Jeffreys, 1961, 16). Az afrikai és a délkelet-ázsiai ekviheptaton xilofon skálák vizsgálatával Blench szintén bizonyítja a kulturális kapcsolatokat, azonban úgy véli, hogy az afrikai xilofonok elterjedtsége és sokfélesége arra enged következtetni, miszerint Afrikában alakulhatott ki a hangszertípus és valószínüleg a maláj kereskedők zenj rabszolgái által a 7-12. században terjedhetett el Délkelet-Ázsiában (Blench, 2010, 242). Mivel a xilofonok eddig ismert legkorábbi ábrázolása a 8 . század végére, 9. század elejére datált, ami Jáváról a Borobudur templomegyüttes ábrázolásairól ismert, a kérdés még nem eldöntött (Morton, 1976, 54). Ráadásul a xilofonok legarchaikusabb, hangszertest nélküli típusait a Fülöp-szigeteken, Melanéziában és Ausztrália középső területein egyaránt ismerik, ezért ezek meglétét nemigen lehet az arab kereskedők által közvetített afrikai hatással magyarázni (Hornbostel, 1933, 284). Illetve a résdobok történeti adatainak komparatív áttekintése is arra enged következtetni, hogy ezek az ausztronéz nyelvü népcsoportok migrációja következményeként jelenhettek meg az afrikai kontinensen (Brauer-Benke, 2018, 153). Fontos azonban azt is hangsúlyozni, hogy egy-egy hangszer diffúz jellegü elterjedése és az adott kultúrában megjelenése korántsem jelenti azt, hogy az adott afrikai népcsoport kultúrájára messzemenő hatással lehetett egy másik Délkelet-Ázsiában található kultúra, ahonnan az adott hangszer származhat (Blench, 1982, 91).

Jelen tanulmány egy kevéssé ismert afrikai hangszertípus, az afrikai citerák történeti áttekintésével szintén a délkelet-ázsiai kapcsolat lehetőségét kívánja megvizsgálni. ${ }^{1}$ Habár a citera típusú hangszerek a szubszaharai Afrika keleti és középső részén jellegzetes hangszernek tekinthetőek, és csekély mértékben, de Nyugat-Afrika délkeleti részén is elterjedtek, azonban az afrocentrizmus általánosító ideológiája miatt (a közkeletủ ismeretek szintjén) a különböző dobtípusokhoz vagy a xilofonokhoz képest alig ismertek. Ez nagyrészt annak köszönhetö, hogy a világzenei fesztiválok afrikai előadói dominánsan a nyugat-afrikai régióból származnak, ezért egy általános ,afrikai zene és afrikai hangszerek” áttekintésben a legtöbbször szó sem esik a föleg Kelet- és Közép-Afrikában elterjedt afrikai citeratípusokról.

A citerák legfőbb morfológiai jellegzetessége, hogy a húrok a hangszer-test egész hosszán párhuzamosan átívelnek. Ebből kifolyólag a hangszer egész teste rezonátorként működik. A citera szó a latin kithara származéka, amely kifejezés eredetileg a líra továbbfejlesztett változatára utalt. A nemzetközi organológiai rendszerezés a citera típusú hangszerek több csoportosítási rendszerét is kialakította. Az angol hangszertipológiai csoportosítás alapján az egyszerü citerák osztályán belül különbség tehető a vályú, a csöves, a tutaj és harang citerák között (Midgley 1996, 164). Emellett pengetéssel szólaltatják meg a hosszú citerákat, a pszaltériumokat, a csembalót, a virginált és a spinétet, illetve ütéssel szólaltatják meg a cimbalmot, a klavikordot és a zongorát. Ebben a csoportosítási rendszerben jól láthatóan nem túl következetes módon a morfológiai alapú csoportosítás áthajlik a megszólaltatás 
módja szerinti csoportosításba. A német organológusok által kidolgozott szigorúan morfológiai alapú csoportosítás megkülönböztet cső, tutaj, tábla (lap), héj és keretciterákat, amely osztályozási rendben példákat is hoznak, ahol jól látható, hogy bizonyos citeratípusok afrikai és délkelet-ázsiai elterjedést egyaránt mutatnak (Hornbostel - Sachs 1914, 577-578). ${ }^{2}$

Az Afrikában is elterjedt citera típusú hangszerekről a legkorábbi híradás a Kr.e. 1. évezredben keletkező Jadzsurvédában szereplő víná polikord botcitera típus, amelynek feltalálója Narada az utazó zenész, védikus bölcs (Prajnananda 1973, 468). A délkelet-indiai Mahábalipuram (Mamallapuram) 7. századi sziklatemplomának ábrázolásain szintén megjelenik a víná botcitera ábrázolása (Kaufmann 1981, 178). (1. kép) A 7. században Indiából kiindulva a Bengáli-öblön át terjedt el a botcitera hangszertípus Indonéziába, ahonnan az Indiai-óceánon átívelő mig-

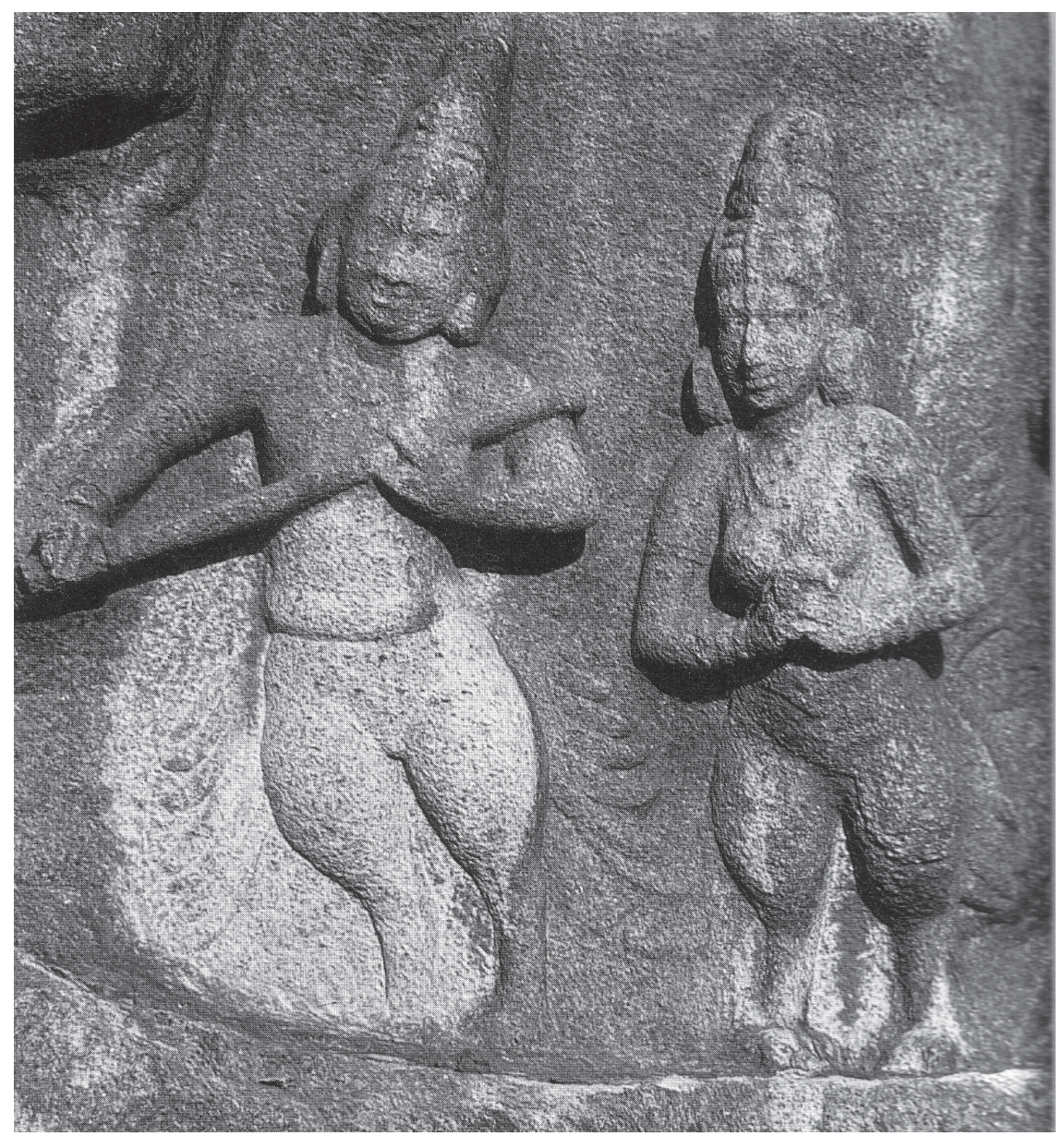

\1. kép: Botcitera ábrázolása, Mahábalipuram, 7. század (Kaufmann 1981 nyomán) 
rációval eljutott Kelet-Afrika partvidékére (Blench 2014, 688). A jávai Borobudur templomegyüttes 900 körüli szoborábrázolásain szintén megtalálható a botcitera hangszertípus (Morton 1976, 54). (2. kép) Szintén Indiából tengeri úton terjedt el Vietnám déli részén, ahonnan a 11. században északi irányban Thaiföld és Mianmar területére is eljutott (Blench, 2014, 688). A víná botcitera típusból kialakuló egyhúros (monokord) botciterák az India északkeleti részén elterjedt toila, a thaiföldi $p$ ' $i$ nam tao, a kambodzsai sátiev, a celebeszi dunde és falundo, a Szumba-szigeti jungga és a Halmahera-szigeti sulepe, valamint a Madagaszkáron, Tanzániában, a Kongói DK-ban és Zimbabwéban elterjedt sese (de Hen, 1976, 88). ${ }^{3}$ Szintén az észak-indiai bìn (rudra vīnā) botciterából kialakult rokonhangszerek még a Fülöp-szigeteken fennmaradt dungadung, kudlung és a tabokok (Wrazen 1986, 41). (3. kép)

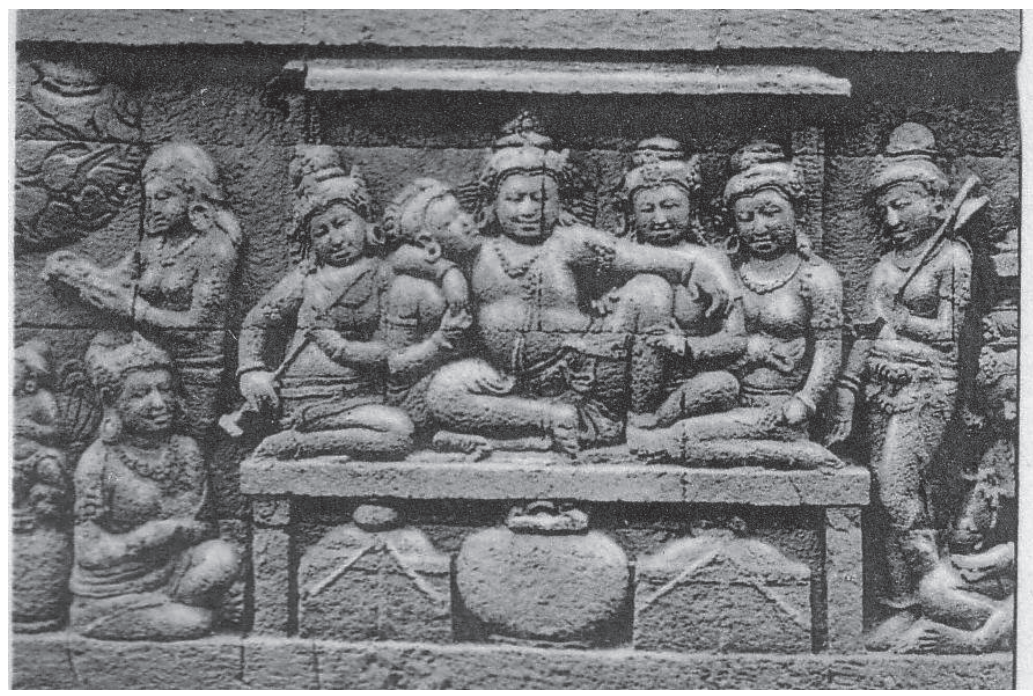

^2. kép: Botcitera ábrázolása, Borobodur, 900 (Morton 1976 nyomán)

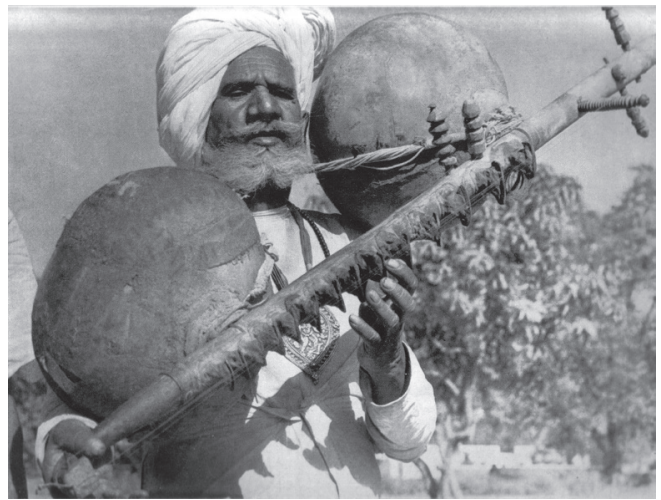

\3. kép: Viná botcitera, Radzsasztán (Daniélou 1978 nyomán) 
A botciterák esetében a húr végigfut egy botforma hangszertesten, amire érintőket faragtak és tökhéj vagy egyéb anyagú rezonátor van szerelve (Daniélou, 1978, 90). Jellemző játékmód, hogy a lopótök rezonátort a mellkashoz szorítják, amely játékstílus Délkelet-Ázsiából és Közép-Afrikából is adatolható (Collaer, 1979, 32). (4. kép) A botciterák morfológiai szempontból két fö csoportra oszthatóak. A hengeres botformájú citeratípusok Indiában, Laoszban, Thaiföldön, Kambodzsában, Indonéziában és Kelet-Afrikában elterjedtek (Sachs, 1929, 181). A botciterák másik típusánál a hangszernyak szögletes kidolgozású, amely típus elterjedési területe Indonézia (Celebesz, Halmahera, Ternate, Banggai és Szumba) Madagaszkár, illetve Kelet- és Közép-Afrika (Sachs, 1929, 201). Afrikában a különböző botcitera típusok elterjedési területe Burundi, Kenya, Kongói DK, Malawi, Mozambik, Ruanda, Szudán, Tanzánia, Uganda és Zambia (Blench, 1984, 167). (5. kép)

Mivel a kelet és közép-afrikai botciterák felépítésüket tekintve rokoníthatóak az indiai, az indonéz és a madagaszkári botcitera típusokkal, a hangszertípus valószínüsíthetően az Indiai-óceánon átívelő korai hajózó népességmozgások által jelenhetett meg Afrikában (Jones, 1971, 167-171). Más vélemények szerint a madagaszkári botciterák morfológiai vizsgálatai inkább arra engedtek következtetni, hogy a hang-
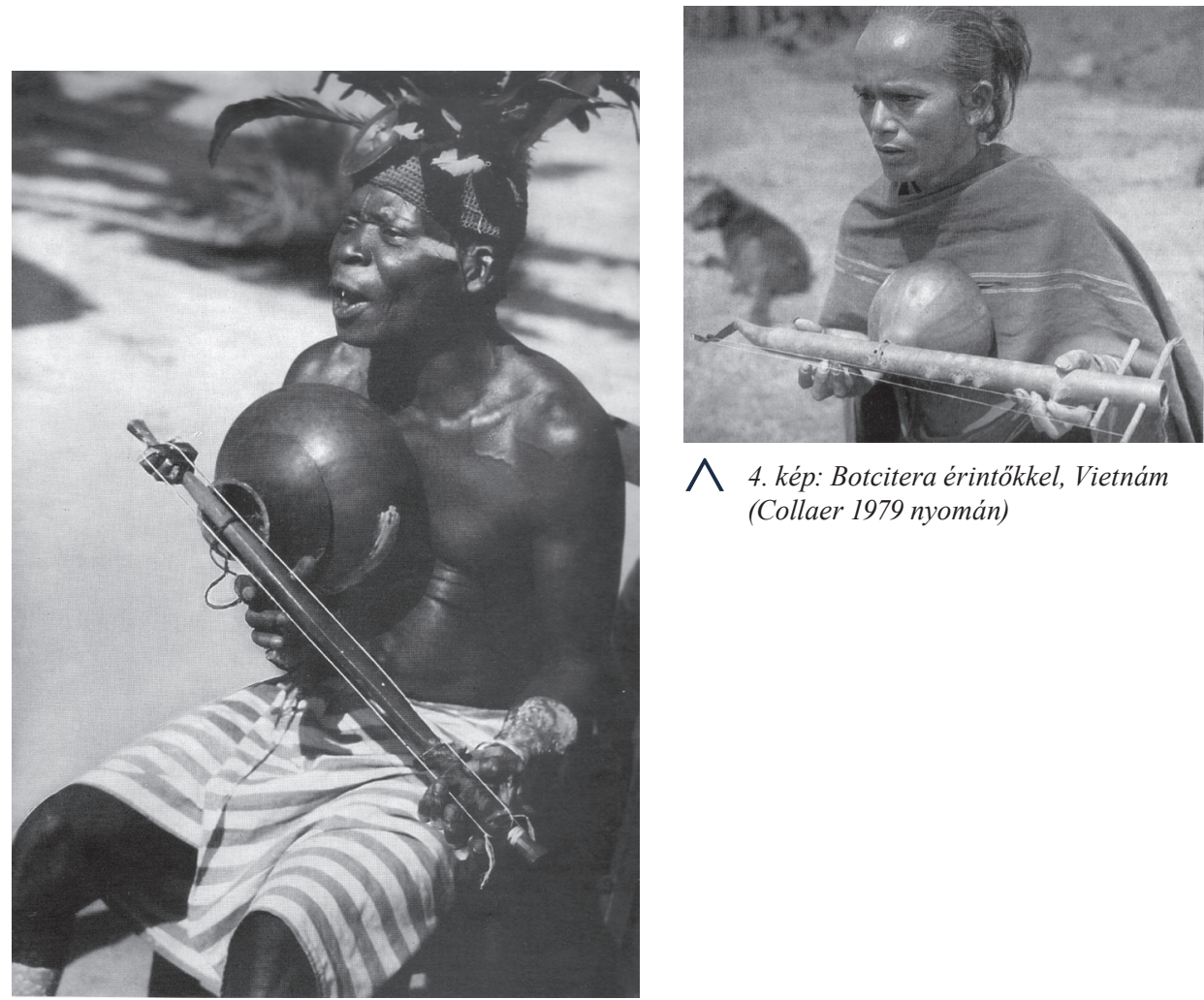

^ 4. kép: Botcitera érintőkkel, Vietnám (Collaer 1979 nyomán)

^5. kép: Botcitera érintőkkel, Kongói DK (Gansemans-Schmidt-Wrenger 1986 nyomán) 
szertípus az afrikai kontinensről származhat (McLoad, 1977, 199). A madagaszkári botciterák jellegzetessége a hangszernyakon alul és felül egyaránt kialakított 3-4 érintő és a két részből összeállított kabaktök rezonátor. ${ }^{4}$ Ezek a morfológiai jellegzetességek az afrikai botciterákon szintén megtalálhatók, míg a korábban rokonított celebeszi botciterákon nem. Viszont az India keleti részén élő dravida nyelvủ sora népcsoport körében elterjedt jengjurangrai elnevezésü botcitera típuson hasonló két részből összeállított kabaktök rezonátor található (Sitapati, 1933, 23). A Kongói DK keleti részén a basi népcsoport körében elterjedt nzenze négyszögletes hangszernyakú botciterára szintén két különálló részből összeragasztott, nagyméretü tökrezonátort illesztenek (Merriam, 1982, 176). A nzenze botcitera végén három érintőt alakítanak ki, de a három húr közül csak az egyik fut az érintők fölött és a másik kettő a hangszernyak két oldalával párhuzamosan van végigvezetve. A három érintő segítségével elméletben négy hang képezhető, de nem minden érintőt fognak le és a szabadon rezgő húrokkal rövid basszushangzásszerü kíséretet produkálnak.

A Kongói DK déli részén élö luluva népcsoport körében elterjedt luzenzu elnevezésű háromhúros botciterán a legmagasabb hangú húr elnevezése férfire („mulume”), a legmélyebb hangú húr nőre (,muhaji”) és a középső hangmagasságú húr a fiúra (,,songaluwe”) utal, amely elnevezések az erősen patriarchális szemléletet tükrözik és ezért a legmagasabb húr a felsőbbrendü, ami a férfiakat jelképezi (Laurenty, 1960, 115). A Kongói DK népcsoportjainak botcitera elnevezései áttekintése szintén igazolja a hangszertípus diffúz elterjedését: kabongo lunzenze, luba luzenzu, bali és luntu lusese, lega, mamwu és vira sese, ikela isese, songye tusese, moba senze, komo nsenze, kusu zenze, lombi és hima nzenze, bembe, luisa és shi zeze, zela dizeze, bubu dzendze, holoholo dyedye, mbuja djedje, nkundo djedji, konda idjendje, mongo ndjendje, ngombe djinge (de Hen, 1960, 152). Ráadásul a Közép és Kelet-Afrikában elterjedt botciterák zeze/nzeze/nzenzelenzenze elnevezését és ezek metaplazmusait (szavakon belüli morfológiai változások) nem kizárólag a botciterákra alkalmazzák, mert szintén ezt a kifejezést használják a vályúcitera és a fidula típusok megnevezésére, mint például Tanzánia középső részén a gogo népcsoport íjhárfa típusának és a busman szandave népcsoport zenéló ijtípusának szintén zeze az elnevezése (Blench, 1984, 167). A szuahéli zeze terminus egyértelmủen a botcitera hangszertípus leírásaként fogható fel: ,zeze: aina mojawapo ya kinanda cha kamba chenye tungi la kitoma au ubao ulio bapa" - úm. 'egyfajta húros hangszer, amelynek tökedény vagy lapos fadarab alkotja a testét' (KKS 1981, 322). Amelynek nem kizárt, hogy végső forrása az óegyiptomi dzedze íjhárfa elnevezés lehetett (Sachs, 1929, 202). Ebben az esetben a terminus az ókori egyiptomi ijhárfákkal együtt, azok elnevezéseként kerülhetett Közép- és Kelet-Afrikába és vált a később megjelenő húros hangszertípusok általános terminusává. A botcitera hangszertípus az arab karavánok segítöi, a nyamwezik által terjedt el a Kongói DK népcsoportjai körében (Coart - de Haulleville, 1902, 125). Az arab karavánok által a botciterák megjelenése adatolható a Kongói DK északi részéről, az Ariwimi-folyó vidékéről, és délről a luba és a lala-bisa népcsoportoktól is, akik által Zambiában is elterjedt a hangszertípus (Costermarns, 1947, 629). 
Kelet-Afrikából a 19. századtól adatolható a botcitera típusok jelenléte a luguru, a makonde, és a jao népcsoportok körében és általuk más népcsoportok is megismerték (Kubik, 1982, 112). Tanzániában a tengerparti régióban Dar es-Salaam és Zanzibár, illetve a Pangani-folyó környékén elterjedt 3 érintős, 2 húros botcitera típusok jellegzetes, villás végződésủ kialakításúak. ${ }^{5}$ Hasonló 2 húros botcitera típus elterjedése adatolható az ország keleti régiójából a nyamwezi népcsoport köréből. ${ }^{6}$ Malawi déli részén a jyo népcsoportnál használt négyszögletes hangszernyakú sese elnevezésü botcitera típus a Zambézi-völgy kereskedelmi útvonala mentén került a yao népcsoporthoz (Kubik, 1982, 112). Azonban az átvételek során megfigyelhetö, hogy a helyi zenészek a saját zenei igényeiknek megfelelően kisebb módosításokat is eszközölnek a morfológiailag megegyező hangszertípuson. Mert a közép-afrikai típusoktól eltérőn a sese már négy húros, de a többi típushoz hasonlóan csak három érintőt alakítanak ki a hangszernyakon, ami bizonyítja a hangszer átvételét. Szintén helyi fejlesztés, hogy a hangszernyak végén három kis, mozgatható, húrhangoló fadarab van, illetve a hangszer azon oldalán, ahol a tök-rezonátor van, a húr végére egy hajlított szárú tollat illesztenek a húr fölé kb. $1 \mathrm{~mm}$ magasságban. A megpendített húr rezegve csak kicsit érinti a tollat, ami által súrlódó hang keletkezik (Kubik, 1982, 112). Ugyanez a botcitera a szomszédos chewa rokon népcsoport körében zeze elnevezéssel ismert (Malamusi, 1996, 62). (6. kép)

A Madagaszkáron elterjedt szögletes botcitera típusokkal kapcsolatban már korán felvetődött annak a lehetősége, hogy még Indonéziából hozhatták magukkal a „hova”, vagyis a szabadok történelmi kasztját alkotó népcsoport ősei (Hornbostel, 1933, 139). Madagaszkár malgas lakosságának szögletes botcitera típusa a lokanga voatavo vagy dzedze vagy jejy voatavo. A „dzedzi” (vagy a szuahéliben ,jejy”) kifejezés csak a partvidékre jellemzö. A „voatavo” jelentése kabaktök és a „dzedzi”

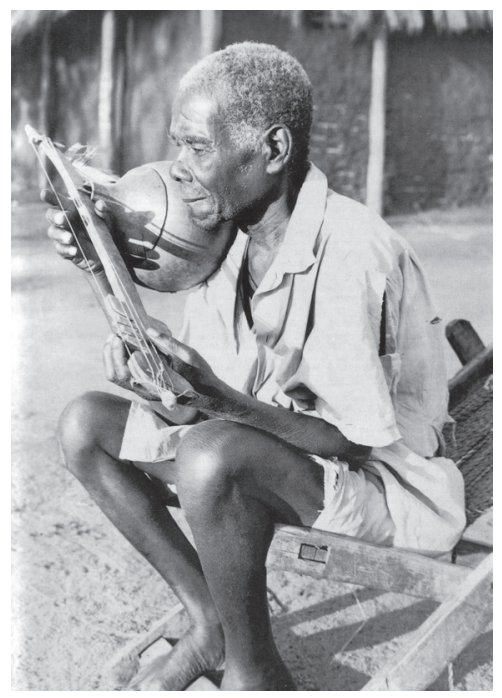

\. kép: Botcitera érintőkkel, Malawi (Kubik 1982 nyomán) 


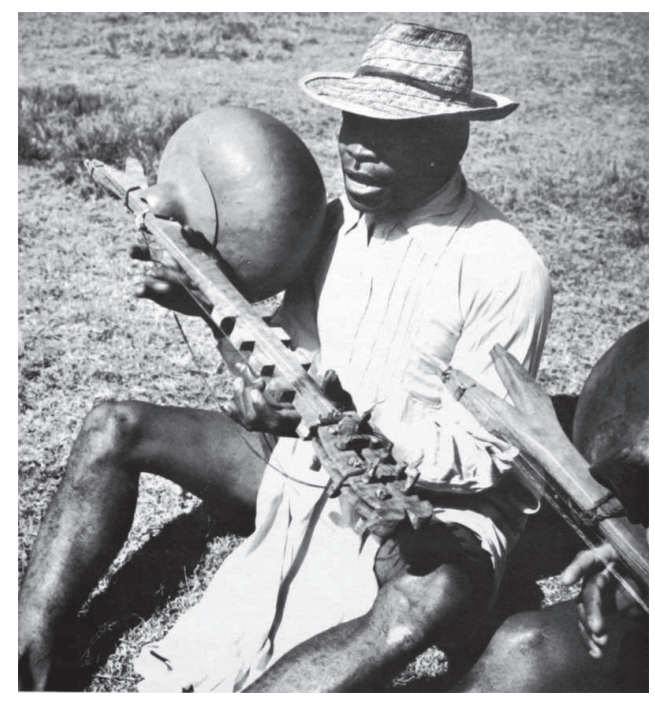

\. kép: Botcitera érintőkkel, Madagaszkár (NGDMA 1984 nyomán)

terminus valószínüsíthetően a közép-afrikai elterjedtséget mutató zeze botcitera típus elnevezésével rokonítható (McLeod, 1977, 198). Madagaszkáron a sziget belsejében a hangszertípus elnevezése a lokanga voatavo, amelynek jelentése „fidula kabaktökkel". A hangszertípust eredetileg a nemesség használta, majd a későbbiekben a rabszolgák körében terjedt el. A lokanga voatavo hangszertípust általában szóló hangszerként, epikus énekek, családi és falusi ünnepek kíséretére használják. (7. kép)

Az 1970-es évekre az eredetileg egy-két rafia húros hangszerből, 11-13 fémhúros hangszertípusokat fejlesztettek ki. A Madagaszkár keleti részén élő betsimsaraka népcsoport szintén az epikus énekek, az ún. „ridzsa” kíséretére használják a jejy voatavo botciterát, amit az énekesek családon belül örökítenek át egymásnak (McLeod, 1977, 210). Mivel a jejy voatavo botciterán a játék bonyolult technikát igényel, a zenészek egyik jellemzője az ősz haj, amely a több évtizedes gyakorlást mutatja. A betsimsaraka népcsoport körében elterjedt 3 érintős jejy voatavo felépítését tekintve egyértelmüen rokonítható a közép- és kelet-afrikai botcitera típusokkal. Összességében az afrikai botcitera típusok morfológiai jegyei arra mutatnak, hogy az Indiai-óceánon átívelő kereskedelem által jelenhetett meg Kelet-Afrika partvidékén és onnan került át a Madagaszkár nyugati részén élő malgas népcsoporthoz, amire a hangszertípus malgas-swahili keverék terminus $d z e d z i$ voatavo elnevezése is magyarázatul szolgálhat (Blench, 1984, 169).

A Hornbostel-Sachs féle besorolás a botcitera típusú hangszerek alcsoportjába sorolja az ún. hárfaciterákat („Harfenzither”, vö. Hornbostel-Sachs, 1914, 16). Illetve a Hornbostel-Sachs hangszertipológia rendszert 2008-ban felülvizsgáló MIMO (Musical Instrument Museums Online) konzorcium a hárfaciterának besorolt mvet 
és egyéb elnevezésü, húrtartó lábas hangszereket továbbra is a citerák (314.22) közé sorolja (Birley - Myers - Villaert, 2011, 15.). Holott azok szintén nem felelnek meg a citera típusú hangszerek főbb definíciójának, miszerint a húroknak a hangszertest teljes hosszában, egymás mellett, és nem egymás felett kellene párhuzamosan végigfutniuk. A hárfaciterák a citerák olyan csoportját alkotják, amelyeknél a hangszer húrjai középen egy lábon futnak át és ebből fakadóan nincsenek érintői. A hárfaciterákon 1 vagy akár 6 tökrezonátor is lehet és a botformájú nyak közepéből vertikálisan egy rovátkolt fa áll ki, amire hegyesszögben 3 vagy 5 húrt feszítenek. (8. kép) Ennek alapján a hárfaciterákat inkább a hárfa típusú hangszerek közé kellene sorolni, mert a kapcsolatuk a „hárfalantokkal” erősen valószínűsíthető, és egyáltalán nem kizárt, hogy egy hasonló hangszer lehetett az archetípus, amely a niger-kongói (mande és nyugat-atlanti ág) nyelvcsaládhoz tartozó népek migrációja révén kerülhetett a térségbe, ahol nagyobb tökrezonátor hangszertestet szereltek rá, illetve a közép-afrikai hárfa típusok fából kialakított hangszertesteinek formája is hatással lehetett a magasított húrtartó-lábas helyi hangszerek kialakulásában. Sőt minden szempontot figyelembe véve annak is felvetődik a lehetősége, hogy a magasitott húrtartó-lábas afrikai hangszereket egy teljesen önálló csoportba kellene sorolni.

A hangszertípus eredete a dél-indiai kinnarí hárfacitera hangszertípusig vezethető vissza, amelyeknél nagyméretủ recézett húrtartó lábakat alkalmaztak, illetve

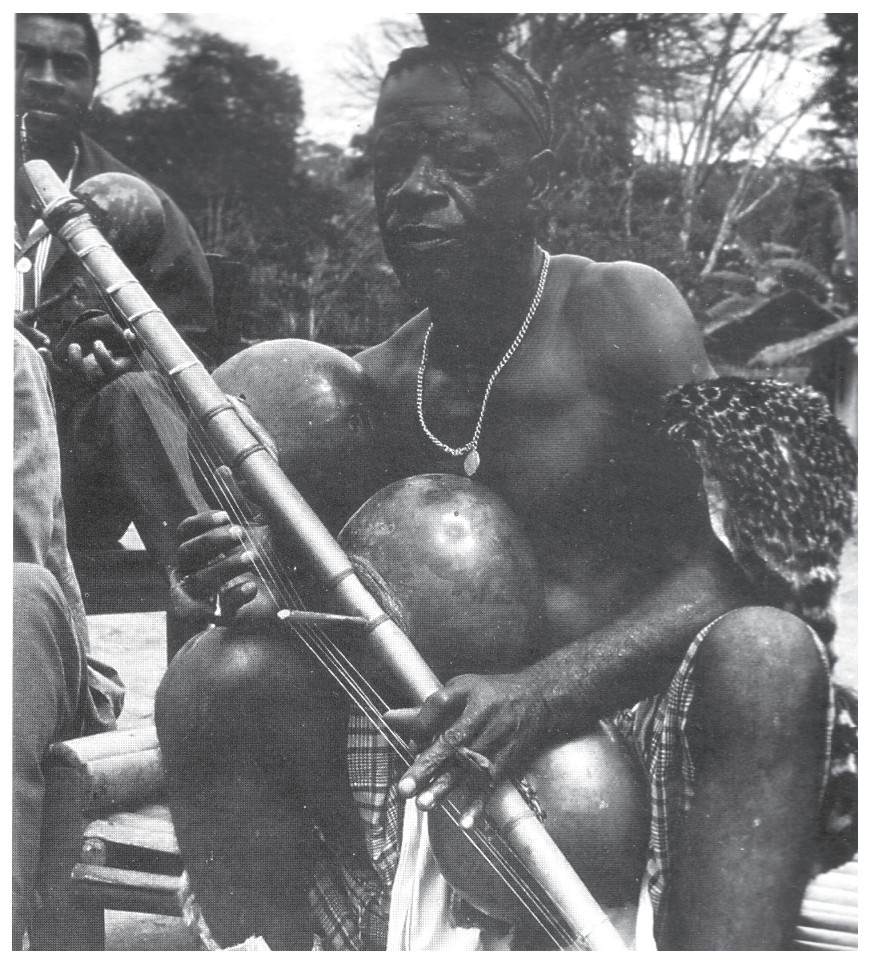

^ 8. kép: Mvet hárfacitera, Kamerun (Gansemans-Schmidt-Wrenger 1986 nyomán) 
a kameruni hárfaciterák felépítése egyértelműen rokonítható a borneói dajakok enkratong elnevezésủ recézett húrtartólábas hárfatípusaival (Sachs, 1923, 125). Egy másik hangszertípus a szabályozható membrános homokóra dobtípusok hasonlósága miatt vetődött fel annak lehetősége, hogy valamikor a Kr.e. 2. században kapcsolat lehetett India és Afrika között és a nyugat-afrikai homokóradobok az ebben az időszakban megjelenő homokóradobok leszármazottai lennének (Marcel-Dubois - Auboyer, 1941, 226). Az elmélet alátámasztására szolgálhat, hogy a mai Szudán északi részén található Meroé romjai reliefjeinek stílusa, illetve indiai elefántok ábrázolása szintén igazolni látszanak a kapcsolat lehetőségét (Arkell, 1951, 57). A Meroitikus Királyság 4. században bekövetkezett hanyatlása után a nílus-szaharai nyelvű népek dél-szudáni és kelet-afrikai irányú vándorlásával több korábban ismeretlen hangszertípus is elterjedhetett a közép-afrikai térségben (Wachsmann, 1964, 86). A hárfaciterák elterjedési területe Kamerun déli része, Gabon, Egyenlítői-Guinea, Kongói DK és a Közép-Afrikai Köztársaság déli és nyugati területei (Gansemans - Schmidt-Wrenger, 1986, 112). Egy a térségbeli hárfacitera típusokat vizsgáló komparatív elemzés alapján a hárfacitera eredetileg a fang (pahouin/pangwe) népcsoport hangszere lehetett és tőlük vették át a gbaya, a mbochi és a kongo népcsoportok (Hornbostel, 1913, 330). Ez a megállapítás valószínúleg azzal is összefüggésbe hozható, hogy a korai néprajzi kutatások úgy vélték: a fang népcsoport eredetileg a nílus-szaharai nyelvet beszélő csoportok közé tartozik, akik a Felső-Nílus vidékéről érkeztek a közép-afrikai térségbe, de a későbbi vizsgálatok megállapítása szerint bantu nyelvüek, akik a hausa rabszolgavadászok miatt, a 7-8. században húzódhattak déli irányba a mai lakhelyükre (Appia - Gates, 2010, 415-419).

Afrikában a hárfaciterák legáltalánosabb elnevezése a mvet, ezen túlmenően még az otchendje, mbo loya, baya, ebenza és a ngombi elnevezések szintén ismertek. Kamerun középső részén a tikar népcsoport körében elterjedt 5 húros mbo loya hárfaciterán tíz különböző hangot tudnak megszólaltatni (Wegner, 1984: 35). A mbo loya elnevezésben a több hangszernév előtagjaként szerepelő „mbo” kifejezéshez társul a „loya” jelző, ami a Kamerun középső részén élő tikar népcsoportnál egy zenei- és táncforma elnevezése (Kubik, 1989, 56). (9. kép) A hangszertípus jelenléte a tikar népcsoport Kamerun déli részén élő népcsoportokkal való kapcsolatát jelzi, mert itt a beti, a bulu, az ewondo az eton népcsoportok körében elterjedt mvet, a mvele népcsoport ebenza, Gabon keleti részén a teke népcsoport baya, és a Kongói Köztársaság nyugati részén a makua népcsoport ngombi elnevezésủ hárfacitera típusai egyaránt rokoníthatóak a mbo loya típussal (Gansemans - Schmidt-Wrengler, 1986, 112). Felépítését tekintve a Kamerun keleti részén élő bakoko népcsoport körében elterjedt 4 idiokord húros hárfacitera szintén ide sorolható. ${ }^{7} \mathrm{~A}$ hárfaciterákon a nyugat-afrikai griok-hoz hasonlóan hivatásos énekmondók játszottak, akik a szóbeli hagyományokra épülő mesék és a mítoszok őrzői és előadói voltak (Gansemans - Schmidt-Wrengler, 1986, 112). Az „ongben” vagy „mvet ekan” elnevezésü énekmondók leghosszabb, mvet hangszerrel kísért ún. „eban” énekciklusa akár 12 óra hosszú előadás is lehet (Alexandre, 1974, 3). A teljes jogú énekmondó mesterré váláshoz „mbomo mvet” csak különböző próbák és rituális beavatások után válhatott 


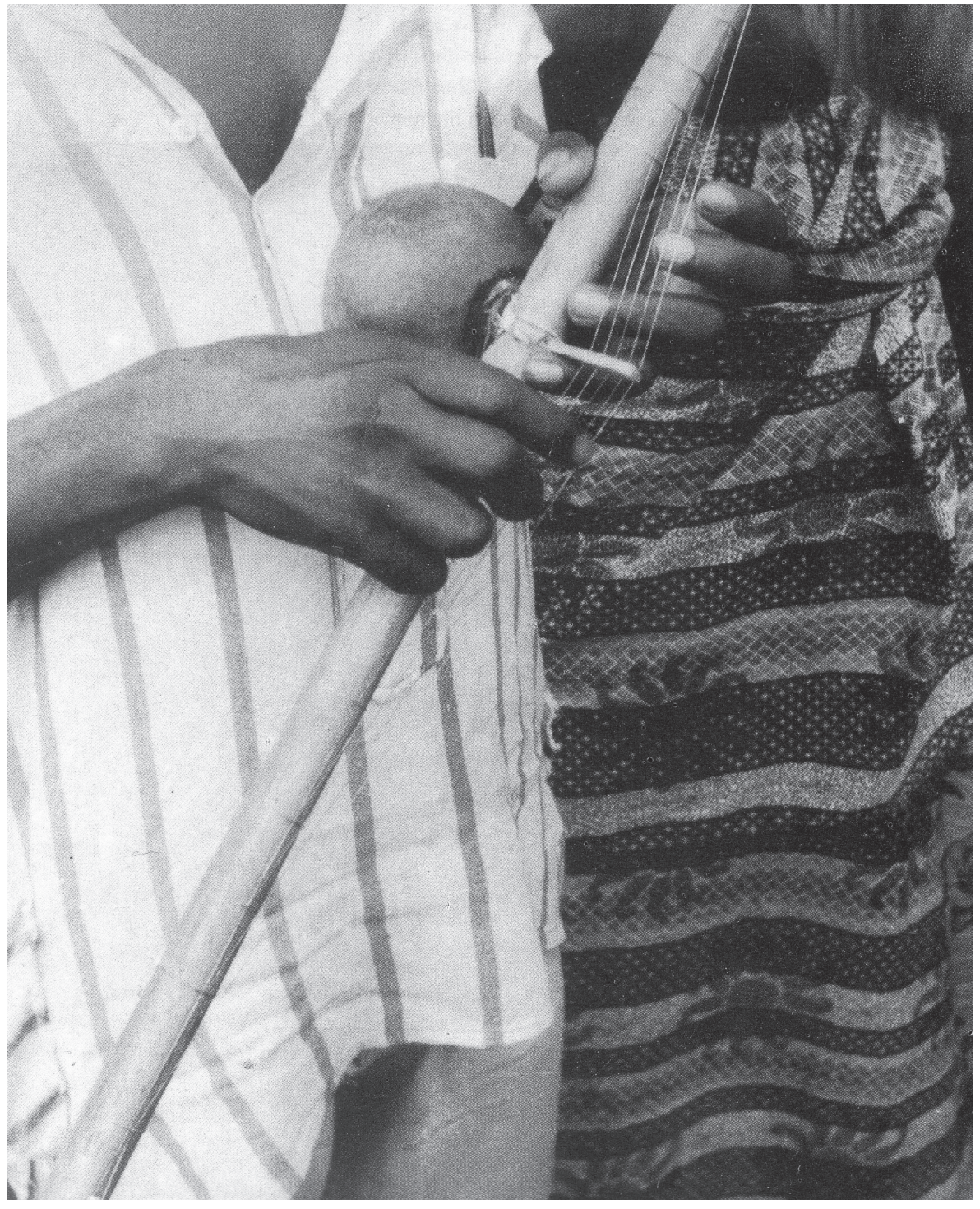

9. kép: Mbo loya hárfacitera, Kamerun (Kubik 1989 nyomán) 


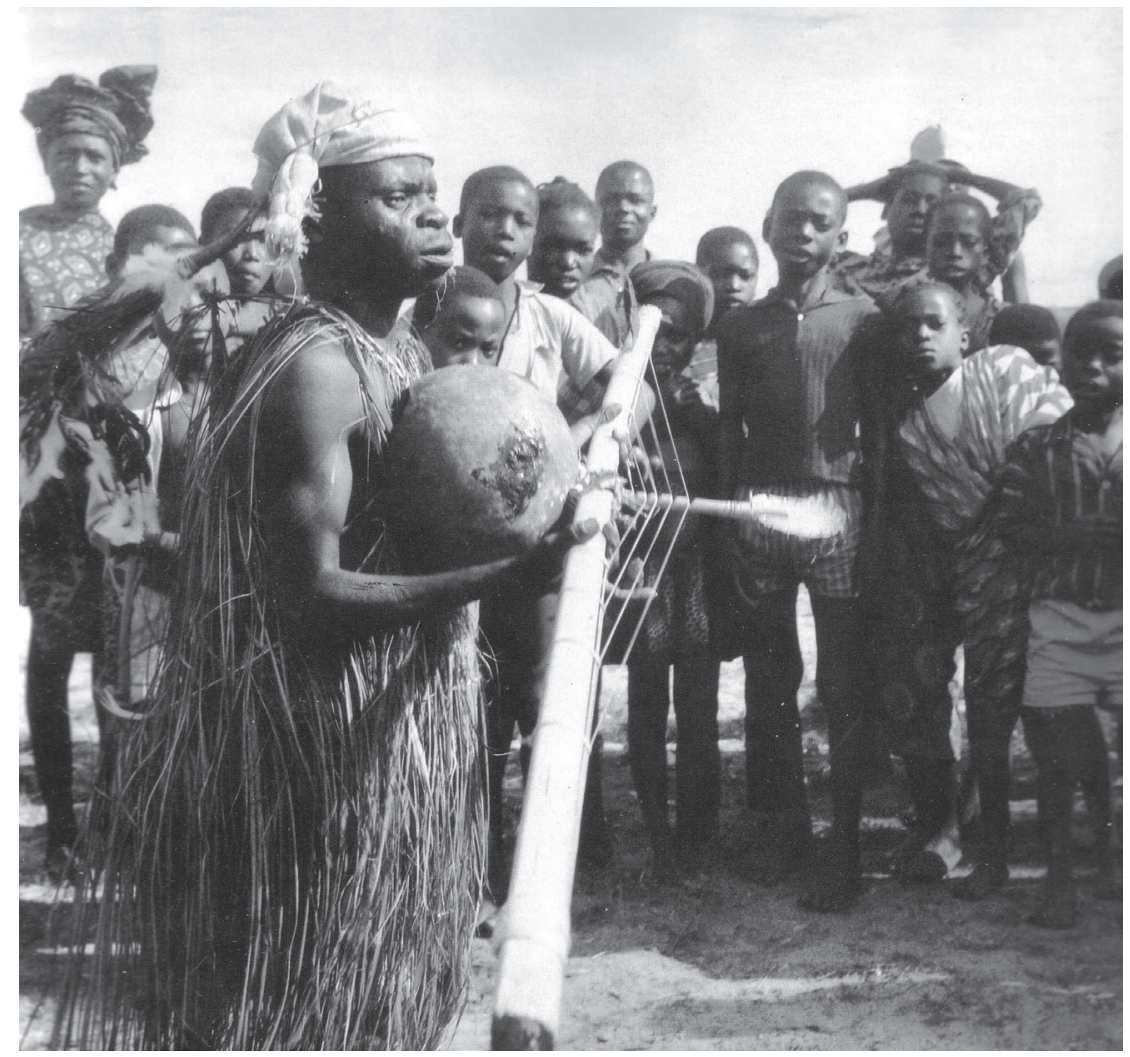

^ 10. kép: Énekmondó mvet hárfaciterával, Gabon (Schmidt-Wrenger 1986 nyomán)

valaki, amelynek során szimbolikusan meg kell halnia és a testi épségét is fel kell áldoznia, ezért sok közöttük a vak, az impotens vagy egyéb testi hibával rendelkező (Alexandre, 1974, 2). (10. kép)

A botciteráktól eltérő, de szintén archaikus citera típus a csőcitera, amely felépítését tekintve egyetlen hosszú, vékony csőszerü hangszertestből és egy arra a teljes hosszában kifeszített húrból vagy húrokból áll, amely archaikusabb formájában idiokord lehetett, vagyis egy rostos növényi agyag oldalából szálirányú hasítással alakíthatták ki rajta a húrozatot. ${ }^{8}$ Fejlettebb formájában már erősebb vagy rugalmasabb anyagból erősítettek rá egyéb anyagból készült húrokat, így kialakítva a heterokord csőcitera típusokat. ${ }^{9}$ A botciterákhoz hasonlóan a csőciterák kapcsán is minden adat arra enged következtetni, hogy az Indiai-óceánon keresztül érkezhetett a hangszer először Madagaszkárra, de a botciteráktól eltérően nem terjedtek el a kontinensen (Blench, 2014, 684). Habár a holland nyelvész Reeland már 1708-ban kimutatta, hogy Madagaszkár lakói, a malgasok nyelve a maláj-polinéz nyelvcsaládhoz tartozik (van Reeland, 1708, 55-139), de a bevándorlás ideje és a kiindulópontja még sokáig vita trágyát képezte. A legújabb kutatások összességében arra mutatnak, hogy a 
malgas népesség alapját képező maláj ősnyelvet beszélő hajósok Borneo déli vagy keleti részéről érkeztek az 5-7. század közötti időszakban (Blench, 2007, 77). Ehhez kapcsolódóan a csőcitera hangszertípus valamikor a 6 . század folyamán érkezhetett Szulavéziről Madagaszkárra, ahonnan a már kevert bantu-ausztonéz nyelvű populáció vándorlása által a 9. században a Comore-szigetekre, majd a 17. században a már bantu elnevezésủ mulumba csőcitera a Seychelle-szigetekre is eljutott (Blench, 2014, 681). A csőciterákról jóval kevesebb ikonográf adat és leírás marad fenn, mint a botciterákról, ezért a hangszertípus kialakulásának feltételezett helye Indokína (Sachs, 1923, 97). (11. kép) A többhúros vagyis polikord csőciterák keleti elterjedési területe a Fülöp-szigetek északi és déli hegyvidéki régiói, Szulavézi, a Maluku-szigetek, Nyugat-Új-Guinea és Kelet-Timor (Blench, 2014, 683). Ezen belül Malajziában különösen sok csőcitera típus található, több regionális elnevezéssel (kecapi, krem, pregan, lutong, satong, tangkungon) és komoly kulturális beágyazottsággal, amely összességében egy hosszan jelenlévő elterjedtséget feltételez (Matusky, 1985, 150). (12. kép)

A csőciterák legnyugatibb irányú elterjedését a Madagaszkáron elterjedt valiha képviseli, amelynek sok altípusa alakult ki. A legtöbb valiha idiokord csőcitera, de újabb fejlesztésként heterokord típusok is kialakultak. Mivel a valiha a délkelet-ázsiai csőcitera típusokkal rokonítható, ezért felmerült annak a lehetősége, hogy a hangszertípus elnevezése a „vádiha”, vagyis 'szent hangszer' kifejezésből eredeztethető (Sachs, 1938, 51). Madagaszkáron északi és keleti hegyvidéki régiójában egy endemikus madagaszkári bambusznak „Valiha diffusa” az elnevezése
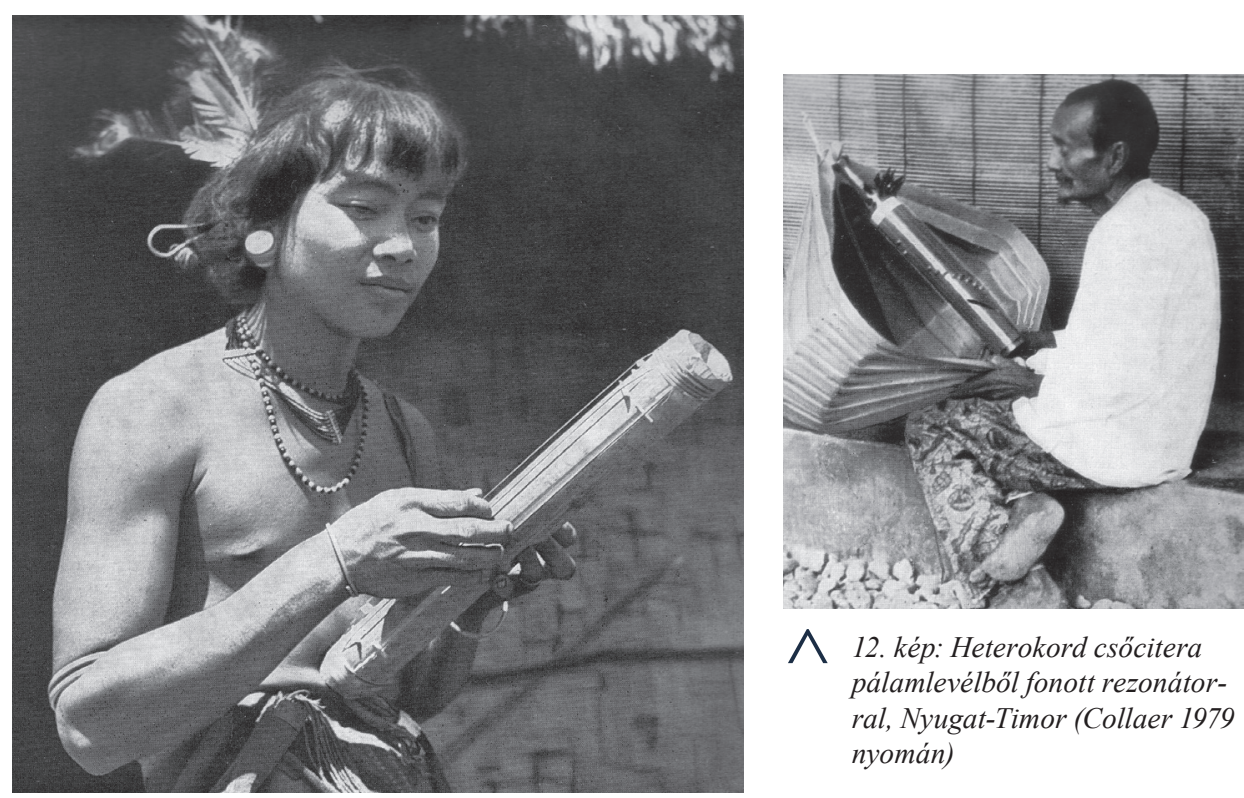

^12. kép: Heterokord csöcitera pálamlevélböl fonott rezonátorral, Nyugat-Timor (Collaer 1979 nyomán)

^ 11. kép: Idiokord csöcitera, Vietnám (Collaer 1979 nyomán) 
és hagyományosan ebből készítették a valiha csőciterákat. Az elnevezés viszont a bambusz helyi általános elnevezéséből a „,vologaz” vagy „volo”-ból származtatható (Surrey - Everett, 2000, 46-47). Ami ilyenformán jó eséllyel a maláj „buluh” vagyis 'bambusz' kifejezésre vezethető vissza, ahol gyakori a 'b' és a 'v' felcserélödése, ezért nem valószínű, hogy kapcsolatba hozható a szanszkrit „vádiha” elnevezéssel. A valiha csőcitera oldalából kihasított húrokat, kobaktökből kialakított kis húrtartó lábakkal emelik el a hangszertesttől, amelyek mozgatásával hangolható a hangszer. Habár a királyság korában a valiha nemesi hangszer volt, de ettől függetlenül a rabszolgák között is elterjedt a használata, mivel azonban a hangszer használatával büntetést kockáztattak, titkolniuk kellett, hogy tudnak rajta játszani (McLeod, 1964, 280). A valiha ezért megmaradt családi használatban, és leginkább a másodszori temetéskor, illetve vallásos szertartások alkalmával szólaltatták meg. Bár akadnak virtuóz játékosok, a valiha megmaradt énekkísérő hangszernek. Az újabb típusok között két alapforma terjedt el: a dobozos formájú valiha vata és a csónak formájú valiha lakana. Az eredetileg szakrális hangszertípus a későbbiekben népzenei és modern popzenei hangszerré vált (McLeod, 1964, 281). Ebből kifolyólag megjelentek a fémhúros, kromatikus hangsorú valihák..$^{10}$ (13. kép) A malgas népesség kirajzásával a 9. században a Comore-szigetekre is eljutott a csőcitera hangszertípus (Blench, 2014, 684), ahol (Madagaszkártól eltérően) az alsóbb társadalmi osztályhoz tartozó szuahéli nyelvű halászok jellegzetes laposcitera hangszertípusa a valiha ndzedze, a szintén elterjedt botciteráknak viszont zeze az elnevezése (Ottenheimer, 1970, 460-461).

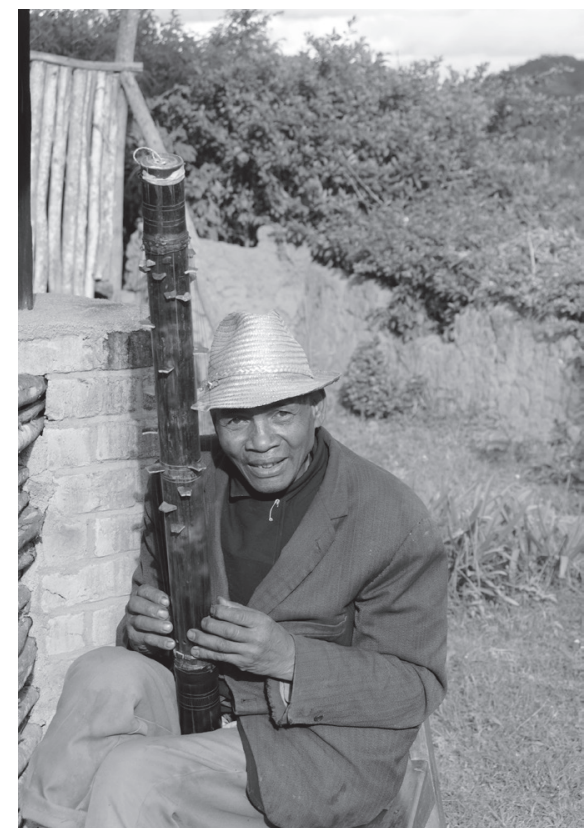

^13. kép: Heterokord valiha csőcitera, Madagaszkár (wikipédia nyomán Rob Hooft felvétele) 


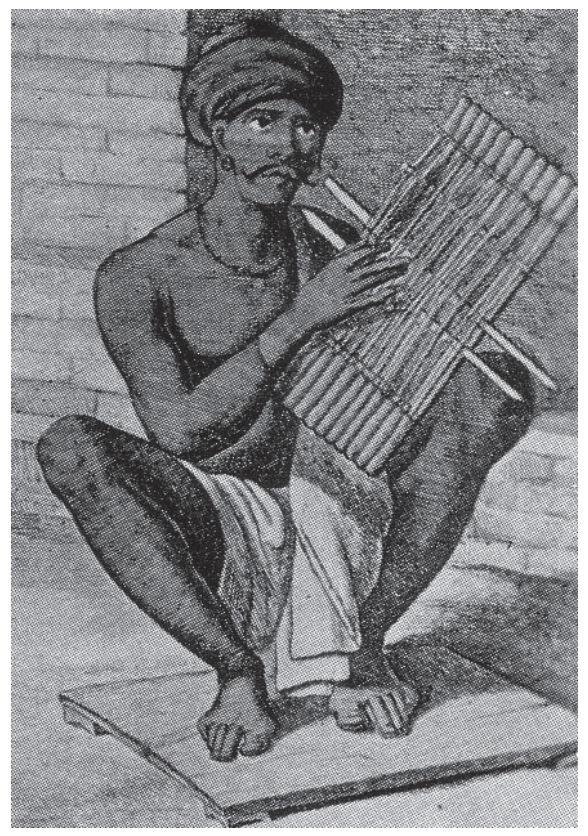

^14. kép: Tutajcitera ábrázolása, Hindusztán (Sachs 1929 nyomán)

Tulajdonképpen több, egymáshoz erösített csöves citerából épülnek fel az ún. tutajciterák. A csövekbe a különleges effektusok elérésére csörgő dióhéjtörmeléket is elhelyezhetnek, illetve a rezonancia erősítése céljával a citera alá tök rezonátort is szerelhetnek. A tutajciterák jellemzően idiokord hangszerek, amelyeken a húrokat a hangszertestként szolgáló csövekből alakítják ki. A csöveket nádból, bambuszból vagy kölesből válogatják össze. A hosszában hasított húrok alá fapálcákat csúsztatnak, amelyek megemelik a húrokat. Mivel a hangszer hangja önmagában nem elég erős, ezért gyakran nagyobb kabaktökből kialakított rezonátort erősítenek a tutajcitera alá. A tutajcitera hangszertípus elterjedéséről Afrikán kívül India középső és északkeleti területeiről vannak szórványadatok, ezért az organológusok már korán felvetették egy korai történeti kapcsolat lehetőségét (Hornbostel, 1933, 289). Bengáliában és Bangladesben a magh (arakan) és India középső részén a gondi népcsoport körében maradtak fenn tutajcitera típusok (Sachs, 1929, 140). (14. kép) Mivel a gondik a dravida népcsoporthoz és a maghok pedig a tibeto-burmai nyelveket beszélő ősi népcsoportokhoz tartoznak, valószínűsíthető, hogy a tutajcitera típusok is egy korai, eddig még nem teljesen feltárt, Indiából kiinduló ősi bevándorlás által jelenhettek meg Afrikában (Sachs, 1940, 233). A tutajciterák afrikai elterjedési területe a 20. század eleji adatok szerint Egyiptom, Szudán, Nigéria, Uganda, Kongói DK, Kenya és Malawi (Sachs, 1929, 140). Ezen túlmenően Beninben a goun népcsoport körében is elterjedt adjalin elnevezéssel, ahol a Porto-Novo királyságban rituális hangszerként alkalmazták (Kinseher, 2005, 260). Burkina 
Faso középső területén a bwa (bwamu) népcsoportnál szintén elterjedt egy hasonló tutajcitera típus, a tian-houn (Boni, 1962, 256). Nigéria középső részén a Jos-platón élő berom népcsoport tutajciterájának jomkwo az elnevezése. A hangszertípus hátára gyakran erősítenek csörgőt is, amit a tutajciterán játszva, rázással szólaltatnak meg (Blench, 2005, 7). A yomkwo citerát ritmuskísérő hangszerként alkalmazzák, ének és tánckísérő szerepkörben. A szomszédos aten népcsoport kiszárított köles szárból (Sorghum vulgare) készíti az idiokord (a húrok a hangszertestből vannak kihasítva) tutajciteráit, amelyen pentaton hangolással hármas sorokba vannak a húrok rendezve és a középső húrokat megkettőzik. (15. kép) Az atenek a tutajciterákat a hüvelykujjaikkal, ún. pörgetős játéktechnikával pengetik, amely Közép-Nigéria népeire jellemző játékmód (Blench, 2005, 7).

A tutajciterák némely típusánál, mint amilyen a Kongói DK-ban elterjedt totombito, a lapciterákhoz hasonlóan, vékony húrtartó lábakat alkalmaznak, a vályúés a lapcitera típusokra jellemző módon a hangszertest végébe vágott vájatokba vezetik húrokat (Alves, 2013, 55). Szórvány elterjedést mutat a Kongói DK északi részén a mombutu népcsoport körében elterjedt seki lapcitera típus, amelynél kis, mozgatható, húrtartó pálcikák alkalmazásával tudják hangolni a hangszert (Tracey, 1966, 49). Az öt húrt a hangszertest két végébe fúrt kis lyukakon körkörösen átvezetik és a mozgatható húrtartó pálcikák segítségével a rezgő húr hosszát szabályozva, a seki behangolható. A kabaktökből kialakított rezonátortestet a hangszertest két oldalára fúrt lyukon átvezetett növényi anyagból sodrott zsinór segítségével rögzítik a hangszertesthez. A seki citeratípust a két kézben tartva a hüvelykujjakkal pengetik. A húrtartó lábak alkalmazása délkelet-ázsiai kapcsolatot sejtet, mert azon a területen elterjedtek a húrtartó lábas kivitelezésủ idiokord citera típusok, amelyekből a bonyolult felépítésü, heterokord, húrtartó lábas távol-keleti citeratípusok is kifejlődtek. A húrtartó láb nélküli lapciterák a délkelet-ázsiai néprajzi analógiákon túlmenően Közép-Afrika keleti részén mutatnak összefüggő területi elterjedést, és amelyek morfológiai sajátosságai és az elnevezések hasonlósága diffúz elterjedést feltételez (Hornbostel-Sachs, 1914, 578). Az afrikai lapciterákhoz nagyon hasonló felépítésủ lapciterák Burmából és a Fülöp-szigetek északi hegyvidéki területeiről is

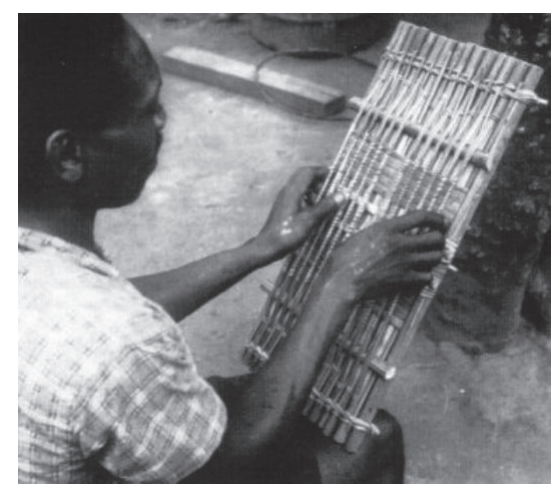

^15. kép: Idiokord tutajcitera, Nigéria (Kubik 1989 nyomán) 


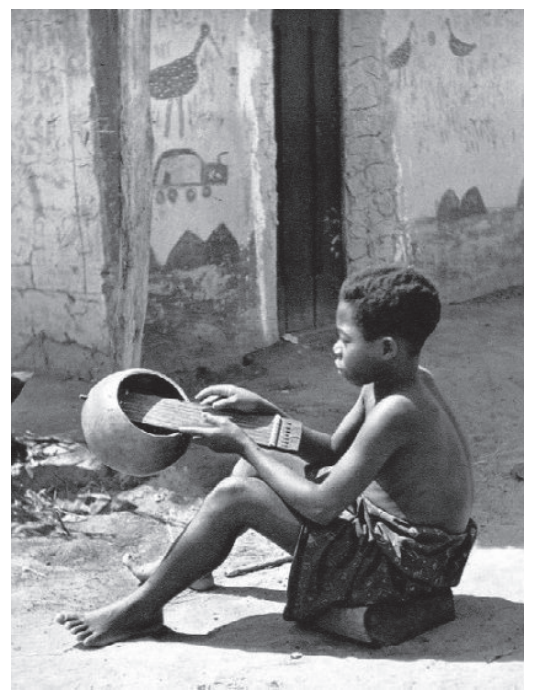

\section{\16. kép: Lapcitera kabaktök rezonátorral, Kongói DK (De Hen 1960 nyomán)}

adatolhatóak, így azok elterjedése egyértelmüen az ausztronéz nyelvủ népcsoportok migrációival magyarázható (Campos - Blench, 2014, 174-179). A Kongói DK északi részén elterjedt lapcitera típus a banzu, aminek a boa népcsoportnál 13 húros, a mangbetu népcsoportnál 11 húros, a zande népcsoport körében 9 húros változatai alakultak ki (de Hen, 1960, 259). A banzu lapciterákon körkörösen tekerik ugyanazt a húrt, ami a hangszertest felső és alsó végén kialakított furatokban fut, amelyek egymástól való távolsága egyben a húrok egymástól való távolságát is szabályozza. Mivel a növényi anyagból készült húrok rezgése önmagában nem lenne elég hangos, a hangszertest aljára vagy egy félbevágott kabaktök rezonátort vagy egy ívesen meghajlított fakéreg rezonátort erősítenek.

A Kongói DK északkeleti részén élő népcsoportok körében a banzu citerával rokonítható laposciteratípusok elterjedtek, mint a makere 10-11 húros gombi, a malele 6 húros nengombi, a mbuja 13 húros ngbandje és a sere 11 húros bwanzi (de Hen, 1960, 156). Morfológiai szempontból és a hangszerelnevezések hasonlósága alapján szintén a banzu citera típussal és elnevezéssel rokonítható Malawiban a yao és a nyanja és Zambiában a chewa népcsoportok körében elterjedt bangwe (Dias, 1986, 244). Szintén ide sorolható a Zimbabwéban elterjedt bagwe lapcitera típus, amelynek lokális jellegzetessége, hogy a kabaktök rezonátort nem a citera aljára erősítik, hanem a lamellofon hangszertípushoz hasonlóan a citera felső végét, nagyobb méretű kivájt kabaktök edénybe helyezik. Ezzel rokonítható megoldást alkalmaznak a Kongói DK keleti részén a luba népcsoportnál elterjedt hét húros ngela elnevezésủ lapcitera típusnál, ahol a hangszertest felső részén egy hegyes nyúlványt alakítanak ki és arra erősítik a kabaktök rezonátort. (16. kép) Malawi északi részén a tumbuka népcsoport körében elterjedt lapcitera típus elnevezése a pango, ami tulajdonképpen a központi és a déli területek népcsoportjai körében elterjedt bangwe lapcitera elne- 
vezés névváltozatának tekinthető (van Zanten, 1983, 90). A szomszédos Tanzánia délnyugati részén a sangu és a safwa népcsoportok körében szintén ismert lapcitera típus a 8-10-14 húros pango, amelynek az egyik végén korábban tök, de az 1980-as években már jobbára bádog rezonátort alkalmaznak (Kubik, 1982, 216). (17. kép) A pango lapciterán tradicionális játékmód esetén a bal kézzel három húrt fognak le és a jobb kézzel, kaszáló mozdulattal pengetik a másik három húrt, de az új játéktechnika már a gitárjátékhoz hasonló. Mivel a hathúros gitár nehezen beszerezhető, a szintén hathúros pango citerán kezdtek el a Közép- és Kelet-Afrikára jellemző kétujjú gitárstílusban játszani, amikor a hangszert rezonátorral felfelé, a gitártartáshoz hasonlóan tartják, a bal kéz három ujjával fogják le a húrokat, a jobb kéz hüvelyk- és mutató ujjaival pengetik (Kubik, 1982, 216). (18. kép)

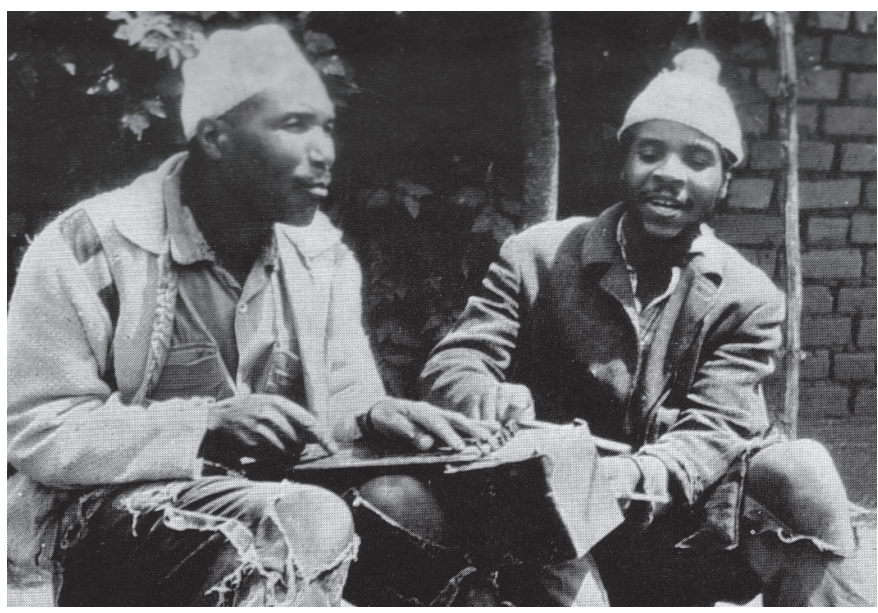

^17. kép: Lapcitera bádog rezonátorral, Tanzánia (Kubik 1982 nyomán)

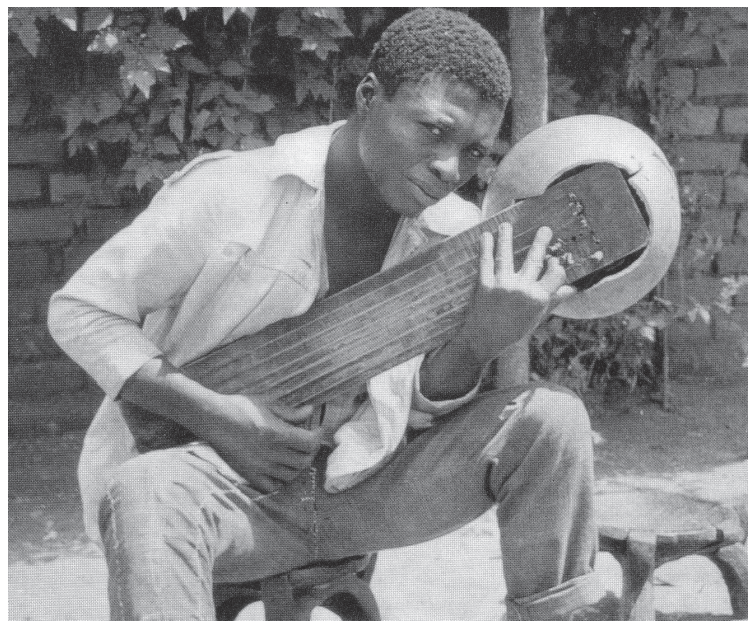

\18. kép: Lapcitera kabaktök rezonátorral, gitárszerü játékmóddal (Kubik 1982 nyomán) 
A lapciterákhoz hasonlóan az ún. vályúciteráknál is körkörösen tekerik ugyanazt az egy húrt, ami vagy a hangszertest felső és alsó végén kialakított furatokban fut, amelyek egymástól való távolsága egyben a húrok egymástól való távolságát is szabályozzák vagy pedig a vályúciterákon alkalmazott fogazott vájatokban vezetik körkörösen végig a hangszertest teljes hosszán. Az ún. vályúciterák közé tartozó Tanzánia nyugati részén elterjedt kinanda elnevezésủ (szuahéli nyelven 'húros hangszer') hangszertípus afrikai megjelenését Frobenius szintén egy Óceániából és Délkelet-Ázsiából érkező „malayonigritic”, vagyis maláj és afrikai keveredést okozó migrációval magyarázza (Frobenius, 1897, 637-650). A későbbi kutatások a Comoreszigetek esetében ki is mutattak egy korai polinéz vagy melanéz letelepedést, majd az őket követő maláj és a bantu expanzióval érkező afrikai népcsoportok keveredését (Brucato - Fernandes - Mazéries - Kusuma - Cox, 2018, 58-68). Azonban a Comore-szigeteken nem maradtak fenn vályúciterák, mert az ott található valiha ndzedze a lapciterákhoz sorolandó (Ottenheimer, 1907, 461).

Mivel a botciteráktól és csőciteráktól eltérően a vályúciteráknak nem maradtak fenn délkelet-ázsiai analógiái, viszont a morfológiailag nagyon hasonló lapciteráknak igen, ezért valószínűsíthető, hogy a vályúciterák nem Délkelet-Ázsiából érkezhettek, hanem Kelet-Afrikában alakulhattak ki a Délkelet-Ázsiából érkező lapciterákból. Emellett megjegyzendő, hogy a magyar nyelvü terminológiákban megtévesztő lehet a „vályúcitera” elnevezés, mert a magyar citeratípusok három fő csoportját a népi elnevezések alapján kidolgozott tipológia után vályúciterának, kisfejes citerának és hasas citerának nevezzük (Sárosi, 1998, 31). A magyar vályúcitera azonban a lapciterák egyik alcsoportjába tartozik, ezért nem tévesztendő össze az afrikai vályúcitera típusokkal.

Az afrikai hangszerek esetében az összefoglaló jellegủ vályúcitera elnevezés több hangszertípust is magába foglal. Közös jellemzőjük, hogy monoxilitikus (egyetlen fából kivájt) kialakításúak és a hangszertest fölött egyetlen húrt tekernek körbe. Az afrikai vályúciterák elterjedési területe Burundi, a Kongói DK keleti része, Ruanda, Tanzánia és Uganda ugyancsak alátámasztják a hangszertípus Indiaióceánon át érkező eredetét (Gansemans - Schmidt-Wrenger, 1986, 118). A nagyobb vályúformájú hangszertípusoknak nincs szüksége kiegészítő rezonátor testre, míg a Tanzániában elterjedt vékony, hosszúkás formájú vályúciteráknál szükséges valamilyen kiegészítő rezonátortest alkalmazása, mert a hangjuk önmagában nem lenne elég erős. A Kongói DK Tanganyika tartományában több lopótökhéj-rezonátoros vályúcitera is fennmaradt. ${ }^{11}$ Tanzánia délnyugati részén a muszlim sangu népcsoport ligombo elnevezésủ 4-14 húros vályúciteráját a hősi énekek kíséretére használták, amely énekek előadása a fönök engedélyéhez volt kötve (Kubik, 1982, 144). A sangu szóbeli hagyományok szerint a ligombo citera a saját hangszerük és miután a hehe népcsoport körében is elterjedt a 19. században, ők kezdték elterjeszteni más népek között is, amit szomszédos pogoro bango, a ngoni libango, és a bena kigombo elnevezések is igazolnak (Lewis-Makala, 1990, 56). A hehe népcsoportnál a ligombo citerán játszó zenészt egy tanítványa kíséri úgy, hogy a játék közben kísérő ritmust üt a citera tökrezonátor testén. (19. kép) Tanzánia középső részén a kagura nép- 


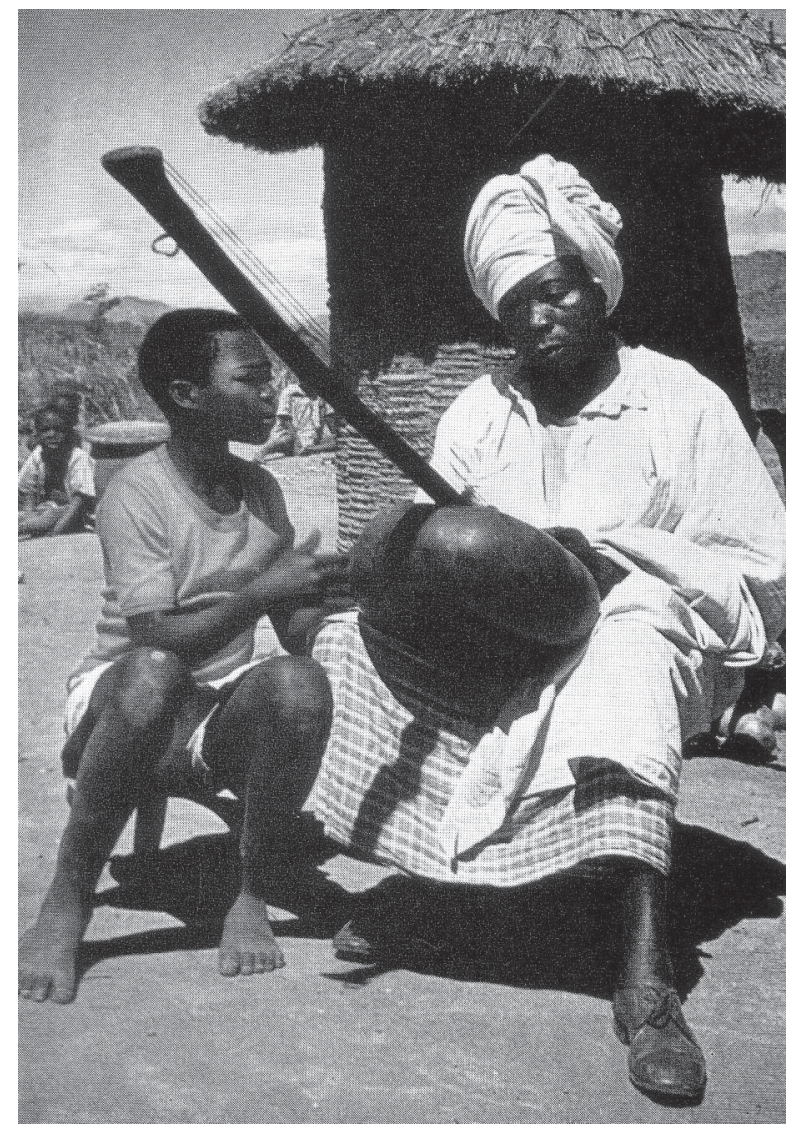

^19. kép: Ligombó vályúciterán játszó zenész és tanítványa, Tanzánia (Kubik 1982 nyomán)

csoport körében elterjedt 6 húros vályúcitera típus jellegzetessége, hogy egyetlen nagyméretü kabaktök rezonátort erősítenek a hangszertest középső részére. A hangszertípus elnevezése a zeze vagy zeze lenye umbo la boga úm. 'tökhéj alakú zeze'. A hangszertest végén olykor faragott férfifejet alakítanak ki. Tanzánia északkeleti részén a zaramo és kwere népcsoportok körében ugyanennek a vályúcitera típusnak zeze vagy zeze lenye umbo la kihori úm. 'dereglye alakú zeze' az elnevezése (Kubik, 1967, 29-32).

Tanzánia középső részén a gogo népcsoport körében elterjedt a sumbi elnevezésü kb. egy méter hosszú rezonátortest nélküli vályúcitera, ami a Tanzánia nyugati részén elterjedt vályúcitera típusokkal rokonítható és azok egyik lokális változatának tekinthető (Kubik, 1982, 126). Mivel a sumbi felépítéséből következően önmagában nem lenne elég erős a hangja, ezért egy lefelé fordított vályúforma kísérőhangszerrel, a pongwaval együtt alkalmazzák. A pongwa oldalán egy kisebb részt kivágnak, és dróttal odaerősítik, amit a zenész játék közben a jobb lába sarkával ritmusosan moz- 
gat, ezáltal ritmuskísértet biztosít a saját citerajátékának. A ritmuskísértet erősítendő a zenész bokájára még egy kengele nevü, kis pergősor is fel van erősítve. (20. kép)

A nagyobb hangszertestủ vályúciteráknak, mint az enanga, nincs szüksége külön rezonátortestre. A hangszertípus hasonló elnevezésekkel a Kongói DK, Uganda, Ruanda, Burundi és Tanzánia népcsoportjai körében egyaránt elterjedt. Az enanga vályúciterákat leginkább a hősepikai énekek kíséretéhez használták és az ugandai haya népcsoport „Mugasa” és Wamala” hősénekeinek muzikológiai vizsgálata alapján úgy vélik, hogy legkésőbb a Bahinda-Babito dinasztiák idején (1500-1963) de nem kizárt már a 15. század előtt is elterjedhetett a használatuk (Mulokozi, 1997, 164). A Viktória-tó déli szigetén élő kerere népcsoportnál az enanga vályúcitera volt az első húros hangszer, ami a 17. század végén terjedt el a körükben (Hartwig, 1972, 455).

A hangszertípus enanga elnevezése lehet bantu eredetü, de nem kizárt, hogy nílus-szaharai, mert Uganda északi részén az acholi nép körében szintén ismert (p’Bitek, 1974, 9). Viszont Uganda középső részén a ganda népcsoportnál egy íjhárfa típus elnevezése az ennanga, ezért nem kizárt, hogy az lehetett az eredeti elnevezés és a játékstílus analógiája miatt kerülhetett át az elnevezés a vályúciterára (Trowel - Wachsmann, 1953, 390).

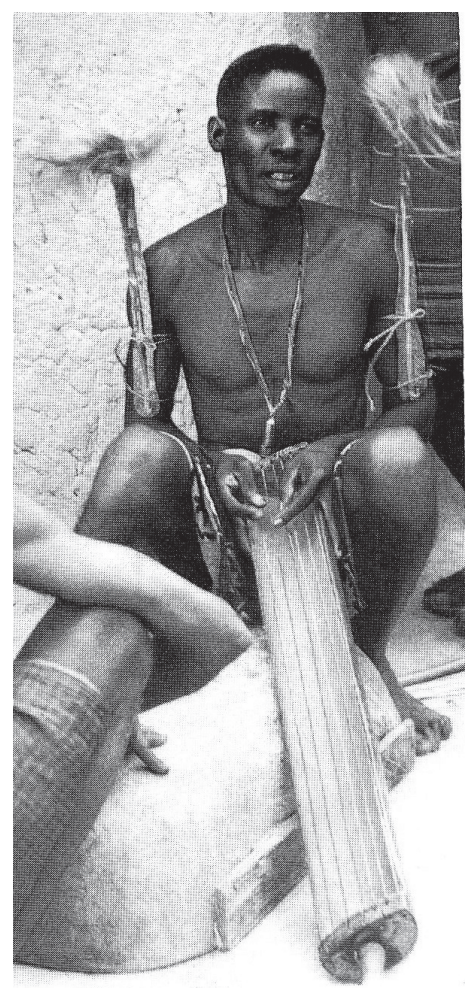

Uganda nyugati és déli területein a kiga, a hima és a kunta népcsoportok körében az enanga vályúciterával általában az előadó a saját énekét kíséri, amelynek témakörei a hősi tettek, imák a hazáért, áldás és bőség kérése a marhaállomány és a tejminőség érdekében (Gansemans - SchmidtWrenger, 1986, 118). Ritkábban a zenészt nagyobb csoport állja körül és tapsolva ritmus- és énekkísértetet alkotnak. Amíg Uganda nyugati részén a hima népcsoport körében jellemzően az uralkodó osztályhoz tartozó nők játszottak az enaanga vályúciterán, addig a délen a kiga népcsoport körében a közemberek hangszere volt (Kahunde, 2012, 213). Ezzel szemben Tanzániában a hima uralkodóknak a zenei szolgáltatásokat egy külön zenész kaszt, a nanga bárdok biztosították, akik az enanga vályúciterán kísérték az epikus dalaikat (Mulokozi, 1983, 284). Ezzel kapcsolatban megjegyzendő, hogy az ugandai himák, amelynek alcsoportjai a nyoro, a toro és nyankore, nem rokoníthatóak a nilota pásztor tanzániai himákkal, akik viszont a ruandai és a burundi tutsik rokonai (Olson, 1996, 225).

^20. kép: Sumbi vályúcitera pongwa rezonátorral (Kubik 1982 nyomán) 
Tanzánia északkeleti részén a haya és a mwanza népcsoportok körében elterjedt a 6-8 húros enanga vályúciterák egyik jellegzetessége a hangszertestbe vágott csillag formájú, vagy ovális bemetszés az „enanga szeme”, amely a funkcióját tekintve hangnyílás és a hang szórásában van szerepe (Lewis - Makala, 1990, 58). Amíg húrokat korábban állati idegből sodorta a falu bőrfeldolgozással foglalkozó mesterembere, az 1980-as években már nejlon vagy fémhúrt alkalmaztak.

Ruandában az inanga vályúcitera a tutsi monarchia idején udvari hangszer volt és a hösénekek kíséretéhez használták, amely dalok repertoárját a történeti énekek, a személyes élmények és a mindennapok konfliktusai ihlették. Ruanda 1700 elötti őslakosai, a tva (pigmeus) népcsoport körében szintén elterjedt az inanga vályúcitera használata, ahol a nők játszanak rajta, akik anhemitonikus (félhang nélküli) pentaton dallamokat elöadva nem használják mind a 6 vagy 8 húrt, mert a magasabb és mélyebb hangokat a pengetés erősségével szabályozzák (Gansemans - SchmidtWrenger, 1986, 118).

A Kongói DK déli részén a shi népcsoport körében elterjedt vályúcitera típusnak lulanga az elnevezése. A fából kifaragott lulanga vályúciterának a két végén négyszögletes fogazatot alakítottak ki, amelyekre körkörösen feltekerve feszítették

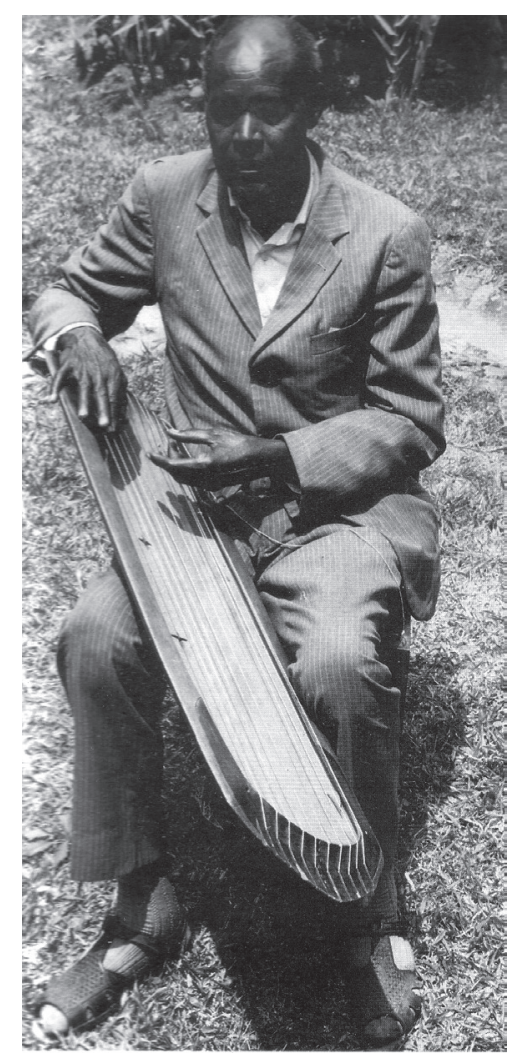

\21. kép: Inanga vályúcitera, Ruanda (Gansemans-Schmidt-Wrenger 1986 nyomán) 
fel a marha ínböl készített húrt. Egyetlen húrt körbetekerve nyolc húrosra alakították a hangszert és a vízszintesen tartott hangszer felső részére estek a mélyhangú, és alulra a magasabb hangú húrok. Viszont ebből következőleg a húrok nagyjából egyenlö hosszúságúak és azonos hangmagasságúak, ezért a húrok finomabb és erősebb pendítésével, illetve adott ponton való lefogásával képezik a különbözö hangokat (Merriam, 1982, 173-174).

Összességében az afrikai citeratípusok történeti áttekintése rámutat arra az aránytalanságra, amit az afrocentrizmus általánosító ideológiája okozott Afrikával kapcsolatban. Mert amíg a nemrégiben (2020.05.22.-én) elhunyt, mandinka származású guineai, a világzene müfajában tevékenykedő énekes és dalszerző Mory Kante az 1987-es Yé-ké-yé-ké címü dala videó-klipjének köszönhetően milliók láthatták a kora hárfalantot, amivel a számát kísérte, és ennek köszönhetően széles körben ismertté vált a hangszer és a griot-ok zenészhagyománya, addig a rokonhangszernek tekinthető mvet hárfaciterákról még napjainkban is csak kevesen hallottak. Pedig a hangszertípus és a rajta játszó „,mbomo mvet” énekmesterek a közép-afrikai törzsfönöki kultúrákban nagyon hasonló szerepet játszottak, csakúgy, mint a kelet-afrikai királyságok enanga vályúciterán játszó „nanga” bárdjai. Ezen túlmenően fontos és érdekes történeti adalék, hogy az afrikai citeratípusok morfológiai és etimológiai vizsgálata, illetve a dél- és délkelet-ázsiai történeti adatok és a néprajzi analógiák komparatív áttekintése alapján felvetődik annak a lehetősége, hogy a húrtartólábas bot- és a tutajcitera típusok, több évszázaddal az európai földrajzi felfedezések időszaka elött, a Vörös-tengeren átívelö népmozgásokkal már eljuthattak a NyugatAfrika keleti részét és Közép-Afrika északnyugati részét magába foglaló régióba. Ezért valószínüsíthető, hogy a valójában nem is a citeratípusok közé tartozó, hanem önálló hangszertípusnak tekinthető afrikai húrtartólábas hárfaciterák a húrtartólábas dél-ázsiai botciteratípusokból fejlődhettek ki. Ezzel szemben a botciterák érintővel ellátott típusai, a csőciterák és a lapciterák bizonyosan az ausztronéz nyelvű népcsoportok által az Indiai-óceánon átkelő migrációval érkezhettek Afrikába, mert azok recens néprajzi analógiái Délkelet-Ázsiában is fennmaradtak. Viszont a csak Kelet-Afrikára jellemző vályúcitera típusok - mivel hasonló délkelet-ázsiai citeratípusok nem ismertek -, valószínűsíthetően már Afrikában alakulhattak ki a hasonló húrfeszítésủ módozatokat mutató lapcitera típusokból. Az afrikai citeratípusok Indiai-óceán irányából érkező megjelenését szintén alátámaszthatja az a tény, hogy a szubszaharai Afrika területén belül Nyugat-Afrika atlanti partvidékére és Északkelet-Afrikába, illetve Délnyugat-Afrikába és Dél-Afrikába nem jutottak el ezek a hangszerek. Ebböl kifolyólag az afrikai citeratípusok történeti áttekintése egyben azt a téves képzetet is cáfolja, miszerint az európai felfedezők és gyarmatosítók érkezése elött Afrika egy, a világtól elzárt kontinens volt. Ugyanis az Indiai-óceán irányából folyamatosan érkeztek a maláj, polinéz, kínai, indiai, arab és perzsa hajózó népek, akik által a különböző kulturális javak, termelési módok és mezőgazdasági termékek megjelentek, majd a kontinensen belüli kereskedelmi útvonalakon akár nagy távolságra is Afrika-szerte elterjedtek. 


\section{Végjegyzetek}

1 Mivel az észak-afrikai elterjedtséget mutató qánún fogólap nélküli citeratípus az arab és az ottomán klasszikus zene hangszereként a közel-keleti régióból származik és Észak-Afrikában is hasonló funkcióban alkalmazták, jelen tanulmány csak a szubszaharai Afrikában elterjedt Délkelet-Ázsiából származó citeratípusok történeti áttekintésére koncentrál.

2 Röhrenzithern (312): Afrika und Indonesien (Gonra, Togo Valiha); Floßzithern (313): Vorderindien, Oberguinea, Zentralkongo, Nördliches Nyassagebiet; Brettzithern (314): Borneo, Nyassagebiet, Maláka, Madagaskar, Schalenzithern (315): Deutsch-Ostafrika, Rahmenzithern (316): Bei den Kru Westafrika,

3 A hangszerelnevezéseknél a The New Grove Dictionary of Musical Instruments terminusai az irányadók.

4 Néprajzi Múzeum, Afrika Gyüjtemény, leltári szám: 25552

5 Néprajzi Múzeum, Afrika Gyüjtemény, leltári számok: 25552, 30174, 124941

6 Néprajzi Múzeum, Afrika Gyüjtemény, leltári számok: 45369, 45370, 45371

7 Néprajzi Múzeum Afrika Gyűjtemény, leltári szám: 135355

8 Néprajzi Múzeum, Afrika Gyüjtemény, leltári számok: 103454, 4000

9 Néprajzi Múzeum, Afrika Gyűjtemény, leltári szám: 96.18 .3

10 Néprajzi Múzeum, Afrika Gyüjtemény, leltári szám: 31979

11 Leltári számok: 3082; 3083; 1982.013 ld. https://mimo-international.com/MIMO/doc/IFD/ OAI_RMAH_94802_NL

\section{Felhasznált irodalom}

ALEXANDRE, Pierre (1974): Introduction to a Fang Oral Art Genre: Gabon and Cameroon mvet. Bulletin of the School of Oriental and African Studies, University of London, Vol.37, No. 1, In Memory of W. H. Whiteley, pp. 1-7.

ALVES, William (2013): Music of the Peoples of the World. 3rd Ed, Boston: Schirmer/Cengage Learning

APPIA, Anthony - GATES, Henry Louis eds. (2010): Encyclopedia of Africa, 1. Oxford University Press

ARKELL, Anthony John (1951): Meroe and India. Aspects of Archeology in Great Britain and Beyond. London, pp. 32-38.

BIRLEY, Margaret - MYERS, Arnold - WILLAERT, Saskia (2011): Revision of the HornbostelSachs Classification of Musical Instruments by the MIMO Consortium. http://www. mimo-international.com/documents/Hornbostel\%20Sachs.pdf

p'BITEK, Okot (1974): Horn of My Love. Nairobi: Heinemann Educational Books

BLENCH, Roger (1982): Evidence for the Indonesian Origins of Certain Elements of African Culture: A Review, with Special Reference to the Arguments of A.M. Jones. African Music, Vol. 6, No. 2 (1982), pp. 81-93.

BLENCH, Roger (1984): The Morphology and Distribution of Sub-Saharan Musical Instruments of North-African, Middle-Eastern, and Asian origin. In: Musica Asiatica 4. PICKEN Laurence (ed.) pp. 155-187.

BLENCH, Roger (2005): The traditional music of the Jos Plateau in Central Nigeria: an overview. Cambridge, pp. 1-10.

BLENCH, Roger (2007): New palaeozoogeographical evidence for the settlement of Madagascar. Azania: Archaeological Research in Africa, Volume 42, pp. 69-82.

BLENCH, Roger (2010): Evidence for the Austronesian Voyages in the Indian Ocean. In: The Global origins and development of seafaring. Ed. by ANDERSON, Atholl - BARRETT, James H. - BOYLE, Catherine V.: Oxford, pp. 239-248.

BLENCH, Roger (2014): Using Diverse Sources of Evidence for Reconstructing the Past History of Musical Exchanges in the Indian Ocean. The African Archaeological Review, Vol. 31, No. 4, Special Issue: Africa and the Indian Ocean (December), pp. 675-703. 
BONI, Nazi (1962): Crépuscule des temps anciens; chronique du Bwamu. Paris: Présence Africaine

BRAUER-BENKE József (2018): Az afrikai tamtam-ok avagy résdobok története és típusai. Afrika Tanulmányok (12), 1-3, 137-156.

BRUCATO, Nicolas - FERNANDES, Veronica - MAZÉRIES, Stéphane - KUSUMA, Pradiptajati - COX, Murray P. (2018): The Comoros show the earliest Austronesian gene flow into the Swahili Corridor. The American Journal of Human Genetics, 102. pp. 58-68.

CAMPOS, Fredeliza - BLENCH, Roger (2014): Heterochord Board and Strip Zithers in the Cordillera, Northern Philippines. The Galpin Society Journal, Vol. 67 (March), pp. 171-180, 45-47.

COART, Emile - HAULLEVILLE, Alphonse de (1902): Notes analytiques sur les collections ethnographiques du Musée du Congo. Les Arts. I. Bruxelles

COLLAER, Paul (1979): Südostasien. Musikgeschichte in Bildern. Bd. 1. Lfg 3. Leipzig: VEB Deutscher Verlag für Musik

COSTERMANS, B. (1947): Muziek-instrumenten van Watsa-Gombari en omstreken. In: Zaïre, Revue Congolaise 6. vol. 1. pp. 629-663.

DANIÉLOU, Alan (1978): Südasien. Musikgeschichte in Bildern. Bd.1. Lfg 4. Leipzig: VEB Deutscher Verlag für Musik

DIAS, Margot (1986): Instrumentos musicais de Moçambique. Lisboa

FROBENIUS, Leo (1897): Der westafrikanische Kulturkreis. Petermanns Geographische Mitteilungen

GANSEMANS, Jos - SCHMIDT-WRENGER, Barbara eds. (1986): Zentral Afrika. Musikgeschichte in Bildern. Bd.1. Lfg. 8. Leipzig: VEB Deutscher Verlag für Musik

HARTWIG, Charlotte M. (1972): Music in Kerebe Culture. Anthropos, Bd. 67, H. 3./4. pp. 449464.

de HEN, Ferdinand J. (1960): Beitrag zur Kenntnis der Musikinstrumente aus Belgisch Kongo und Ruanda-Urundi. Tervuren

de HEN, Ferdinand J. (1976): A Case of Gesunkenes Kulturgut: The Toila. The Galpin Society Journal, Vol. 29 (May), pp. 84-90.

von HORNBOSTEL, Erich Moritz (1913): Die Musik der Pangwe. In: Die Pangwe. Tessmann, Günther (szerk.) vol.2. Berlin (Reprint 1970), 320.

von HORNBOSTEL, Erich. Moritz -SACHS, Curt (1914): Systematik der Musikinstrumente. Zeitschrift für Ethnologie, Berlin 46, 553-90.

von HORNBOSTEL, Erich Moritz (1933): The Ethnology of African Sound-Instruments. Comments on „Geist und Werden der Musikinstrumente” by C. Sachs. Journal of the International African Institute, Vol. 6, No. 2 (Apr.), pp. 129-157., 277-311.

JACOBS, Surrey W. L. - EVERETT, Joy (eds.) (2000): Grasses. Systematics and Evolution. Csiro Publishing

JEFFREYS, Mervyn David Waldegrave (1961): Negro influences on Indonesia. African Music Society Journal, Grahamstone 2/4. 10-16.

JONES, Arthur Morris (1964): Africa and Indonesia: The Evidence of the Xylophone and Other Musical and Cultural Factors. Leiden: Brill

JONES, Arthur Morris (1971): An ancient colonial era. In: Klaus P Wachsmann ed. Essays on music and history in Africa. Evanston: Northwestern University Press, 167-171.

KAHUNDE, Samuel (2012): Repatriating Archival Sound Recordings to Revive Traditions: The Role of the Klaus Wachsmann Recordings in the Revival of the Royal Music of BunyoroKitara, Uganda. Ethnomusicology Forum, Vol. 21, No. 2, SPECIAL ISSUE: Ethnomusicology, Archivesand Communities: Methodologies for an Equitable Discipline (August), pp. 197-219.

KAUFMANN, Walter (1981): Altindien. Musikgeschichte in Bildern Bd. 2. Lfg. 8. Leipzig: VEB Deutscher Verlag für Musik

KINSEHER, Richard (2005): Der Bogen in Kultur, Musik und Medizin, als Werkzeug und Waffe. Norderstedt: Books on Demand

KKS Kamusi ya Kiswahili Sanifu (1981): AKIDA, Hamisi ed. Dar es Salaam: Oxford University Press 
KUBIK, Gerhard (1967): The traditional music of Tanzania. Afrika 8. (2). pp. 29-32.

KUBIK, Gerhard ed. (1982): Ostafrika. Musikgeschichte in Bildern. Bd. 1. Lfg. 10. Leipzig: VEB Deutscher Verlag für Musik

KUBIK, Gerhard ed. (1989): Westafrika. Musikgeschichte in Bildern, Bd. 1. Lfg. 11. Leipzig: VEB Deutscher Verlag für Musik

LAURENTY, Jean-Sébastien Laurenty (1960): Les cordophones du Congo Belge et du RuandaUrundi. Tervuren: Annales du Musée Royal du Congo Belge, vol 2.

LEWIS, Gareth W. - MAKALA, E. G. (1990): Traditional musical Instruments of Tanzania. Dar es Salaam: The Music Conservatorie of Tanzania

MALAMUSI, Moya Aliya (1996): Stringed Instrument Traditions in Southern Malawi. African Music, Vol. 7, No. 3 (1996), pp. 60-66.

MARCEL-DUBOIS, Claudie - AUBOYER, Jeannine (1941): Les Instruments de musique de l'Inde ancienne. Paris: Presses Universitaires de France

MATUSKY, Patricia (1985): An Introduction to the Major Instruments and Forms of Traditional Malay Music. Asian Music, Vol. 16, No. 2 (Spring-Summer), pp. 121-182.

McLEOD, Norma (1964): The Status of Musical Specialists in Madagascar. Ethnomusicology, Vol. 8, No. 3 (Sep.), pp. 278-289.

McLEOD, Norma (1977): Musical Instruments and history in Madagaszkar. In: PIROTTA, Nino (szerk.) Essays for a Humanist. An offering to Klaus Wachsmann. New York: 189-215.

MERRIAM, Alan Parkhurst (1982): African Music in Perspective. New York: Garland

MIDGLEY, Ruth föszerk. (1996): Hangszerek enciklopédiája. Budapest: Gemini

MORTON, David (1976): The Traditional Music of Thailand. Berkeley: University of California Press

MULOKOZI, Mugyabuso M. (1997): The Last of the Bards: The Story of Habibu Selemani of Tanzania (c. 1929-93) Research in African Literatures, Vol. 28, No. 1, The Oral-Written Interface (Spring), pp. 159-172.

NGDMI-The New Grove Dictionary of Musical Instruments I-III. (1984). Szerk. SADIE, Stanley. London: Macmillen Publishers Limited

OLSON, James Stewart (1996): The Peoples of Africa. An Ethnohistorical Dictionary. Westport: Greenwood Press

OTTENHEIMER, Harriet Joseph (1970): Culture Contact and Musical Style: Ethnomusicology in the Comoro Islands. Ethnomusicology, Vol. 14, No. 3 (Sep.), pp. 458-462.

PRAJNANANANDA, Swami (1973): Historical Development of Indian Music: a Critical Study (2nd edition), Firma K. L., Mukhopadhyay

RELANDUS, H. [Adriaan van Reeland] (1708): Dissertationum Miscellanearum, Pars Tertia et Ultima. Trajecti ad Rhenum: Guilielmus Broedelet, pp. 55-139.

SACHS, Curt (1923): Die Musikinstrumente Indiens und Indonesiens. Berlin und Leipzig: Walter de Gruyter \& Co.

SACHS, Curt (1929): Geist und Werden der Musikinstrumente. Berlin: D. Reimer

SACHS, Curt (1938): Les Instruments de Musique de Madagascar. Paris: Institut d'Ethnologie

SACHS, Curt (1940): The History of Musical Instruments. New York: W. W. Norton \& Company

SÁROSI Bálint (1998): Hangszerek a magyar néphagyományban. Budapest: Planétás

SITAPATI, Savaras (1933): Sora Musical Instruments. Bulletin du Music Ethnographie du Trocadero, Paris, pp. 1-8.

TRACEY, Hugh (1966): Musical appreciation in central and southern Africa. African Music Society Journal, Grahamstowne 4. pp. 47-55.

TROWEL, Margaret - WACHSMANN, Klaus P. (1953): Tribal Crafts of Uganda. London: Oxford University Press

WACHSMANN, Klaus P. (1964): Human migration and African harps. Journal of the International Folkmusic Council, Cambridge 16. pp. 84-88.

WEGNER, Ulrich (1984): Afrikanische Saiteninstrumente. Berlin (west): Museum für Völkerkunde

WRAZEN, Louise (1986): The Early History of the Vīnāa and Bīn in South and Southeast Asia. Asian Music, Vol. 18, No. 1 (Autumn-Winter), pp. 35-55.

van ZANTEN, Wim (1983): Malawian Pango Music from the Viewpont of Information Theory. African Music Society Journal, Grahamstowne 6/3. pp. 90-106. 


\section{English Abstract}

\section{African Zithers}

A general historical survey of African zither types cannot fail to highlight the disproportionalities brought about in the study of Africa by the essentialistic ideology of Afrocentrism. Thus the widely known videoclip of the 1987 hit Yé-ké-yé-ké by the late Mory Kante (d. 22nd May 2020), musician and composer of Guinean Mandinka origin has allowed millions to experience the kora harp lute with which he accompanied his song and popularized this instrument as well as the musical tradition of the West African griots, while the obviously related mvet harp zither is scarcely known today. This despite the fact that both the latter instrument type and its specialists, the mbomo mvet master singers, played a very similar role in the cultures of the Central African chiefdoms, as did the nanga bards playing the enanga trough zither in the East African kingdoms. Another important and interesting historical insight provided by a careful morphological and etymological analysis of African zither types and their terminology that takes comparative account of South and Southeast Asian data and ethnographic parallels concerns the possibility of borrowings. Thus stick and raft zither types may well have reached the eastern half of West Africa and the northeastern part of Central Africa several centuries prior to the era of European geographical explorations - owing to population movements over the Red Sea. It seems therefore probable that the African stick bridges harp zithers (in fact a sui generis instrument type rather than a subtype of zithers) developed from South Asian stick zither types. On the other hand, tube zithers and box zithers - fretted-enhanced versions of the stick zither - certainly reached Africa because of the migration of Austronesian-speaking groups over the Indian Ocean, since their recent ethnographic analogies have survived in Southeast Asia as well. By contrast types of trough zither, confined to East Africa, must have developed in Africa from box zither types, which are based on similar techniques of making the strings tense. The hypothesis of African zither types having originated from beyond the Indian Ocean is further strengthened by the absence of these instruments in such regions of Sub-Saharan Africa as the Atlantic coast of West Africa as well as in Northeast, Southwest and South Africa. Thus the historical overview of African zither types also helps refute the erroneous idea that prior to the arrival of European explorers and colonizers the continent was isolated from the rest of the world. In fact seafaring peoples such as the Austronesians, Chinese, Indians, Arabs and Persians did continually reach it, bringing with them cultural artifacts, production techniques and agricultural products among other things, which would then spread over large distances along the trade routes over Africa.
A szerzőröl

PhD, tudományos munkatárs

MTA BTK Zenetudományi

Intézet

About the Author

PhD, Ethno-organologist

Institute for Musicology,

Research Center for the

Humanities, Hungarian

Academy of Sciences

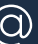

braver-benke.jozsef@btk.mta.hu 